NBER WORKING PAPER SERIES

\title{
LABOR UNREST AND THE QUALITY OF PRODUCTION: EVIDENCE FROM THE CONSTRUCTION EQUIPMENT RESALE MARKET
}

\author{
Alexandre Mas \\ Working Paper 13138 \\ http://www.nber.org/papers/w13138 \\ NATIONAL BUREAU OF ECONOMIC RESEARCH \\ 1050 Massachusetts Avenue \\ Cambridge, MA 02138
}

May 2007

The author is grateful to Alan Krueger, Maitreesh Ghatak, and two anonymous referees for many valuable suggestions and comments. The author also thanks Orley Ashenfelter, David Card, Hank Farber, Kenneth Fortson, Jeff Kling, David Linsenmeier, Bentley MacLeod, Jesse Rothstein, Cecilia Rouse, Matthew Weinberg, Pei Zhu and seminar participants at Princeton University, Stanford, Harvard Business School, Columbia, U.C. Berkeley, Dartmouth, Yale, Oxford, RAND, University of Michigan, and Northwestern for helpful suggestions. Jennifer Ferng provided excellent assistance in compiling the data. Financial support was partially provided by Fellowship for Woodrow Wilson Scholars and the Industrial Relations Section of Princeton University. The views expressed herein are those of the author(s) and do not necessarily reflect the views of the National Bureau of Economic Research.

(C) 2007 by Alexandre Mas. All rights reserved. Short sections of text, not to exceed two paragraphs, may be quoted without explicit permission provided that full credit, including $\odot$ notice, is given to the source. 
Labor Unrest and the Quality of Production: Evidence from the Construction Equipment Resale Market

Alexandre Mas

NBER Working Paper No. 13138

May 2007

JEL No. D18,D2,J0,J3,J41,J5

\begin{abstract}
This paper examines the construction equipment resale market to assess whether equipment produced by the world's largest manufacturer of construction machinery, Caterpillar, experienced lower product quality in facilities that underwent contract disputes during the 1990's. Analysis of auction data reveals that resale market participants significantly discounted machines produced in these dispute-affected facilities. Additionally, pieces of equipment produced in facilities undergoing unrest were resold more often, received worse appraisal reports, and had lower list prices. Taken together, the evidence supports the hypothesis that workmanship at dispute-affected facilities declined, and that the resulting impact on the economic quality of the equipment produced was significant. The dispute was associated with at least $\$ 400$ million in lost service flows due to inferior quality equipment alone.
\end{abstract}

\author{
Alexandre Mas \\ Haas School of Business \\ 545 Student Services Building \#1900 \\ University of California \\ Berkeley, CA 94720-1900 \\ and NBER \\ amas@ haas.berkeley.edu
}


The economic costs of industrial relations events such as strikes, slowdowns or work stoppages can be significant. The evidence from firm-level measures of output and output per worker is strong on this point (Freeman and Medoff 1984; Katz et. al. 1983; Kleiner et. al. 2002). Less is known about the effect of labor unrest on product quality, but there are reasons to believe that this relationship could be sizable. Product quality is linked to effort, and the degree to which workers can reduce on-the-job effort during a labor dispute depends on the firm's ability to monitor employee performance, which can be limited. For example, an equilibrium outcome of Shapiro-Stiglitz-style efficiency wage models is that the more costly it is for the firm to monitor performance, the higher is the wage increase for a given increase in effort. ${ }^{1}$ At face value, this feature implies that when firms demand wage concessions from their workers, the resulting fall in productivity should be most pronounced when productivity is manifested in hard to observe ways. When goods are complex, a dimension of productivity that is particularly hard for firms to measure is product quality. It follows that even when workers are on the job, and the firm is operating at full capacity, employees may still be able to reduce the effort necessary for ensuring the quality of the product in manners that are practically undetectable. Hence, the effect of a disruption in labor relations on the quality of production may be large, but it is an effect that is not easy to ascertain for the firm or, unfortunately, for the econometrician.

In this paper, I propose a series of tests to determine whether a specific labor dispute affected productivity through the reduction in the quality of goods produced. These tests are the result of a detailed analysis of the industrial relations climate within the firm and of the market in which these goods transact. Concretely, I study whether workers at Caterpillar, a manufacturer of construction equipment machinery, produced inferior equipment while working during an extended contract dispute in the 1990's. The tests rely on the proposition that shocks to quality will induce changes in the behavior of participants in resale markets. While product quality is difficult to measure for an assembled piece of machinery, resale market participants had many years to learn about the equipment, and as a result, their actions reveal defects in the machines that the manufacturer may not have been able to detect at the time of assembly. This information is the econometrician's advantage over the firm that I exploit.

\footnotetext{
${ }^{1}$ See Malcomson (1999) (and of course Shapiro and Stiglitz 1984) for examples of Shapiro-Stiglitz-style efficiency wage models. Hendricks and Kahn (1991) develop a model of efficiency wages in a union setting.
} 
The event studied in this paper is a well-known confrontation that occurred between the United Auto Workers (UAW) and Caterpillar through the better part of the 1990's. The dispute, which began when the UAW contract with Caterpillar expired in September 1991 and ended when the next contract was signed in early 1998, was long and contentious by most standards. The dispute spanned two strikes, dozens of brief walkouts, the use of replacement workers, and threats to permanently replace the unionized workers. Ultimately the conflict resulted in the National Labor Relations Board filing 443 complaints against Caterpillar, the most ever issued against one company (Cimini 1998).

As indicated, in order to study the effect of the dispute on quality, an unobservable outcome, I assemble evidence from an analysis of the construction equipment resale market. The dataset contains the resale price, reported condition and resale rate for more than 48,000 pieces of used construction equipment sold at auction. Using these data, I formulate tests of the hypothesis that equipment produced during the period of labor unrest was of reduced quality. These tests are predicated on dynamic models of the durable goods resale market that make predictions on prices and trading volume following quality shocks (eg. Hendel and Lizzeri 1999, Porter and Sattler 1999). In addition, reports on the physical condition of the equipment on the resale market are used in conjunction with prices and resale rates to compile evidence on quality effects of labor unrest.

Analysis of the resale auction data reveals that pieces of equipment produced by workers involved in the dispute were discounted by approximately $5 \%$ in the resale market, received lower quality ratings by independent appraisers, and experienced higher resale rates compared to equipment produced in other plants and other periods. I estimate that the dispute was associated with at least $\$ 400$ million in lost service flows from inferior quality equipment. Because some of these costs were "hidden", that is, not immediately felt by the firm and unknown to the workers, accounting for them helps explain the substantial length of this particular labor dispute through the lens of a war-of-attrition model of bargaining. I find that, ultimately, the labor cost savings that Caterpillar obtained by breaking with the union (which I calculate) most likely exceeded these losses.

The findings in this paper complement several other studies that provide evidence linking the industrial relations and workplace climate to measures of economic performance (eg. Katz et. al. 1983, Freeman and Medoff 1984, Harter et. al. 2002, Kleiner et. al. 2002, Bartel et. al. 2003, Krueger and Mas 
2004, and Mas 2006). This paper is the first to use market outcomes to measure product quality. The advantage of this approach is that it provides measures of employee performance that incorporate both contractible and non-contractible dimensions of effort. The non-contractible dimensions of effort are interesting as they are precisely where a sharp change in working conditions should have the greatest impact. By not considering them, one risks underestimating the productivity effects of disruptions in labor relations. Using market outcomes also allows one to quantify how much disputes cost firms and consumers. A final attractive feature of this analysis is that it is more general than a single-plant case study; since there are numerous production lines affected by the dispute, the paper identifies a general pattern in declining workmanship across many processes.

\section{Background of the Company and the Labor Dispute}

Caterpillar is the world's largest manufacturer of construction, mining, agricultural, forest machinery and other types of equipment. In 1991, the company employed more than 53,000 workers worldwide, including about 38,670 in the United States, and had more than 33 manufacturing facilities around the world. The UAW represents workers in the transportation construction equipment manufacturing sector. In 1991, the union represented about 15,100 Caterpillar employees at plants in Illinois, Pennsylvania, Colorado, and Tennessee.

The conflict originated as the parties attempted to negotiate a contract to replace the one expiring in September 1991. The UAW sought to continue pattern bargaining, by which they would target a company in the industry for negotiations and pressure other companies to sign the same contract. There were early signs that Caterpillar would demand concessions from the UAW. Eckert (1992) reports that as early as October 1990 officials at the UAW local in Peoria "warned that a strike was possible and advised members to start fattening their bank accounts." By July 1991, it became evident that negotiations would be exceedingly difficult when the parties could not agree to a location for the contract talks [Cimini 1998]. Negotiations between the UAW and Caterpillar broke down permanently after Caterpillar refused to accept the contract that the UAW had negotiated with John Deere in October 1991.

In November 1991 the UAW placed 2,400 members on strike in hopes of further pressuring Caterpillar. Caterpillar subsequently locked out 5,650 more workers and laid-off 500 more. In the following months, 8,050 workers were on the picket lines. On April 1, 1992, Caterpillar sent letters to 
striking workers telling them that unless they returned to work by April 6, they would "lose their place in a reduced workforce," and "be replaced by a returning striker, an employee recalled from the layoff, or a permanent new hire." ${ }^{2}$ Facing the threat of replacement workers, and potentially a significant number of workers crossing the picket lines, the UAW called off their strike on April 14, 1992 but did not agree to sign a contract under Caterpillar's terms.

The company's attempt to permanently replace the striking workers seemed especially unfair to some workers. Franklin (2001: p. 161) reports that "the gripes were not about the losses the union had suffered but the arrogance of the company to think it could [function] without the union's help." One worker, Randy Morrell, said that "we were told all through the 1980 s that we had to share ideas and benefits with the company... and here came 1991, and the whole thing was jerked out from under us...we are not going to reap the benefits." without a contract and sporadically participated in brief wildcat strikes. Workers complained of daily harassment by management and arbitrary disciplining and there is evidence that workers reduced their effort on the job as a response. In fact, a reduction of effort was official UAW policy as its leaders initiated a "work-to-rule" campaign in Caterpillar plants, in which workers follow orders precisely but take absolutely no initiative on the job (Cohen 2002).

In the early years of the dispute, there were rumors that the quality of Caterpillar machines being produced was substandard. The UAW cited a series of customer complaints that had been submitted to Caterpillar as evidence (Mining Week 1992) as well as an internal memo written by Aurora, Illinois plant manager Chuck Elwyn. The memo, a copy of which was provided to a reporter for the Engineering NewsRecord, states that quality objectives for July 1992 had been missed by a wide margin ranking as "the poorest performance in the plant's history" and "the worst month by any plant in the entire corporation's history." Several months later, The Economist reported that Caterpillar "customers and dealers are beset with rumors of a slide in productivity and product quality" (The Economist 1993).

Another sign of the turmoil Caterpillar experienced during these years are the large number of complaints filed with Occupational Safety and Health Administration (OSHA) originating from unionized

${ }^{2}$ Quoted in Daily Labor Report (1992: p. A-4).

${ }^{3}$ Quoted in Franklin (2001: p. 165).

${ }^{4}$ Quoted in Engineering News-Record (1992). 
Caterpillar plants. Numerous OSHA complaints indicate a poor industrial climate, either because the employer creates conditions that adversely affect workers safety or because workers wish to pressure the employer for improved working conditions. Figure 1 plots the number of complaints to OSHA from 1984 to 2001 from workers at Caterpillar and Deere, Caterpillar's closest American competitor. OSHA complaints originating from Caterpillar plants were stable through 1991, but increased by $225 \%$ in 1992 , and then by an additional $92 \%$ in 1993 . By contrast, there is no perceptible increase in the number of complaints originating from Deere plants over the dispute period. Figure 2 plots the percentage of complaints that led to Department of Labor (DOL) violations at Caterpillar. There is no apparent change in the percentage of complaints that led to DOL violations during the dispute period, suggesting that workers were not submitting frivolous complaints.

When new contract talks broke down in June of 1994, the UAW initiated another strike, this time with 13,000 workers. This strike lasted until December 1995; during this period, Caterpillar staffed its plants with reassigned white-collar workers, full-time new hires, and temporary workers. In addition, onethird of the UAW workers crossed the picket lines. Despite the strike, Caterpillar sales increased 23\% in 1994 and 11\% in 1995, and earnings rose $46 \%$ in 1994 and 19\% in 1995. The second strike again ended without a contract for the UAW workers. Finally, after six and a half years without a contract, in March 1998 the UAW ratified a new six-year agreement with Caterpillar covering 13,000 Caterpillar employees. The conditions for the new contract were almost identical to the ones that Caterpillar had offered over the past six and one-half years. ${ }^{5}$

\subsection{Construction equipment production}

Although automation has an important role in the assembly of construction equipment, humans have substantial discretion over the quality of construction equipment produced. Even with the use of flexible machine tools, which were introduced in Caterpillar plants during the early period of the dispute, the production process was not fully automated owing, in part, to relatively short product cycles; the market for construction equipment is characterized by a vast amount of product differentiation — there are 353 different Caterpillar models of equipment in the sample used in this paper. According to Boiarsky

\footnotetext{
${ }^{5}$ The contract called for an immediate wage increase ranging from $2 \%$ to $4 \%$, provided for three lump-sum payments of $3 \%$ of earnings in 1999, 2001, and 2003, and maintained COLA for all but entry-level employees. The company also agreed to hire back 160 workers fired for strike-related activities
} 
(1994), "robots at Caterpillar did not prove to be much of a boon. In areas such as welding, robots could not do a satisfactory job. The welding done by humans was superior." There are many other important steps in the production process of construction equipment that require substantial human intervention. For example, equipment is painted manually, which if not done adequately will result in premature rusting. Nuts and bolts must be applied to the equipment using the correct torque. Too little torque will results in a bolt that does not hold the parts tightly and a bolt with too much torque can break during installation. As a result, there is potential for workers to affect the quality of goods produced

\section{Discussion of the Data and the Evaluation Strategy}

I assembled a dataset describing the characteristics of more than 48,000 pieces of equipment sold at auction between January 1994 and September 2002. The underlying data are proprietary to Equipment Watch (EW), a company that sends agents to construction equipment auctions to report on the characteristics of equipment sold. Aside from the last bid, agents record the type of equipment sold, model, model year, serial number, the location of the auction, the auctioneer, a brief description of the equipment sold, auction date, and appraise the condition of the machine on a six point scale, ranging from "poor" to "excellent". 6 Contractors and leasing companies use these data to estimate the value of their construction equipment.

In addition to the auction transaction data, EW also provided a serial number guide that reports the shipment year, country of origin and model type for each piece of equipment produced. ${ }^{7}$ I use serial numbers to construct tight bounds on the production year of the construction equipment, estimates for assembly line level production, age of the production line, and time the equipment spent in inventory. In addition, identifiers embedded in the serial numbers of all equipment can be used to infer the production line it was manufactured in. The algorithm used to construct these measures is described in Appendix A.

Ideally, precise comparisons of equipment produced at plants affected by labor dispute to those that were not could be made using detailed identifiers for the year of production and plant of production for each piece of construction equipment. Unfortunately, these data are proprietary. In the absence of

\footnotetext{
${ }^{6}$ The appraisals were not available to bidders at the time of auction.

${ }^{7}$ About 6,000 pieces of equipment were discarded from the dataset because their serial number could not be matched to the serial number guide, possibly because the serial numbers were misrecorded. An additional 110 observations were excluded from the dataset because the equipment was new at the time of auction. The resulting dataset contains 48,043 transactions.
} 
such data, the strategy in this paper is to use the serial number of the equipment to infer its country of origin. ${ }^{8}$ Caterpillar is a large company, production is multi-national, and many identical models of equipment are produced in a variety of countries. While data for union versus non-union US Caterpillar production is publicly unavailable, plant-level data from Harris InfoSource show that of plants established before 1991, organized plants employed 15,100 manufacturing workers and non-organized plants employed only 2,250 in 1998. Further evidence that most US production occurred in organized plants can be seen from OSHA inspection records. Between 1984 and 2001 there were 142 complaints to OSHA from workers in unionized Caterpillar plants as opposed to only 10 from workers in unorganized plants. Additionally, equipment produced in non-unionized facilities in the United States may have contained parts that were manufactured in organized plants. For example, the Caterpillar plant in Pontiac Michigan, which is unionized, produced engines that were installed in other plants. Because unionized plants produced a large share of US-made equipment during the dispute, dispute-affected equipment is therefore defined as any piece of equipment produced in the US at the time of the dispute. The comparison group consists of equipment produced abroad, primarily in Europe and Japan.

Table 1 summarizes the auction market transactions data that will be used in the analysis. The table shows descriptive statistics for US and foreign machines, for pre-dispute, dispute, and post-dispute vintages. The table reveals that the dispute-affected and comparison groups are fairly balanced; approximately $40 \%$ of the equipment in my sample was produced in the US, and about $19 \%$ of the equipment was produced in the US during the dispute. ${ }^{9}$ To compare, approximately $47 \%$ of all equipment produced during this period originated from plants in the United States. However, the table reveals several important differences in US and foreign equipment: pieces of equipment produced in the United States sold for a higher price at auction, tended to be from older production-lines, and were more likely to be classified in very good or excellent condition, were produced in older production lines, and were more

\footnotetext{
${ }^{8}$ With a valid serial number, country of origin can be determined using the Equipment Watch serial number guide. While it is possible to identify the production line, using publicly available information there is no way to match the production line to a plant of origin.

${ }^{9}$ Despite the fact that the data were collected from 1994 onwards, several years after the dispute had begun, much of the equipment in the sample was produced during the dispute. About $43 \%$ of the equipment in the sample was produced before the dispute. An implication of this sampling scheme is that any estimates of the dispute effect will be based on differences in outcomes for relatively older equipment.
} 
likely to be sold at auction in the United States. These differences are driven in large part by composition; the mix of models produced in the United States differs from the mix produced abroad.

\section{Model of the Construction Equipment Resale Market}

Because quality is unobserved, inference must be based on observable characteristics of equipment, including prices and volume of trade. Models of the construction equipment resale market can guide the analysis by generating testable predictions on the relative prices and resale rates for goods that experience accelerated physical depreciation. The following rational expectations model is adapted from the dynamic two durable goods economy with no asymmetric information outlined in Hendel and Lizzeri (1999). ${ }^{10}$ The model links closely to the empirical exercise, generating predictions for the relationship between quality, resale prices, price depreciation, and volume of trade. The model also sheds light on the implications of consumer heterogeneity in the empirical identification of a quality change.

In the model, consumers have heterogeneous preferences over the valuation of quality. In the context of the construction equipment market this kind of heterogeneity could arise in a number of ways, including productivity differences across buyers. ${ }^{11}$ Consumers are infinitely lived and equipment life is two periods. Consumers' valuations are parameterized by $\theta$, and lie on the interval $[\theta, \bar{\theta}]$. In a given period, consumers with preference $\theta$ enjoy utility $q \theta$ if they purchase a good of quality $q$. Consumers can only hold one piece of equipment at a time and must decide what quality of equipment to consume for that period. Consumers who sell their equipment incur a transaction cost, $\mathrm{T}$.

There are two kinds of equipment, US and foreign. Every period there is an exogenous flow $y_{u}$ of new US goods and $y_{f}$ of new foreign goods into the market. I will assume that quality is deterministic and observed by all parties in the market (I will discuss the case of random quality realizations and asymmetric information later). New US and foreign equipment exhibit quality level $v$, while used US and foreign equipment have quality $w_{u}$ and $w_{f}$ respectively. The initial ordering of quality is assumed to satisfy $v>w_{u}>w_{f}$. This ordering implies that new US and foreign equipment are of the same quality,

\footnotetext{
${ }^{10}$ A similar model is outlined in Porter and Sattler (1999).
} 
but that foreign equipment depreciates more rapidly than the US good. The assumption that foreign equipment depreciates more rapidly than US equipment is posited to match the facts from the actual resale market. In the empirical portion of the paper I show that in narrowly defined resale markets, US equipment produced in non-dispute periods garners a premium. The assumption that new US and foreign equipment are of the same quality can be justified on the basis of warranties and quality control. If quality control is effective, defects should be mostly latent. Warranties ensure that new defective machines can be repaired or replaced at minimal cost to the consumer. After outlining the remainder of the model I will consider what happens to resale prices and resale rates of US equipment relative to foreign equipment following a decline in $w_{u}$ - the quality of used US equipment.

Let $P_{t o}$ denote the price of a good produced in country $o$ (US or foreign) in period $\tau$ ( 1 or 2 ) of the good's life. Assuming the buyers engage in stationary strategies, consumers have the following options in this model, resulting in corresponding discounted utilities:

- Buy used foreign equipment each period:

$$
V_{1}(\theta)=\left(\theta w_{f}-P_{2 f}\right) /(1-\delta)
$$

- Buy used US equipment each period:

$$
V_{2}(\theta)=\left(\theta w_{u}-P_{2 u}\right) /(1-\delta),
$$

- Buy new US equipment and keep it for two periods:

$$
V_{3}(\theta)=\left(\theta\left(v+\delta w_{u}\right)-P_{1 u}\right) /\left(1-\delta^{2}\right),
$$

- Buy new US equipment each period:

$$
V_{4}(\theta)=\left(\theta v-P_{1 u}-T+\delta P_{2 u}\right) /(1-\delta),
$$

- Buy new foreign equipment each period:

$$
V_{5}(\theta)=\left(\theta v-P_{1 f}-T+\delta P_{2 f}\right) /(1-\delta) .^{12}
$$

\footnotetext{
${ }^{11}$ Studies have shown evidence of persistent productivity differences across firms, even within narrowly defined industries (see e.g. Baily, Hulten and Campbell 1992).

${ }^{12}$ The remaining alternative, buying new foreign equipment and keeping for two periods, is ruled out by Proposition 8 of Hendel and Lizzeri (1999). Through self-selection, buyers who wish to buy and keep new equipment always purchase US equipment.
} 
Denote $\theta_{y f}$ as the preference of the consumer who is indifferent between purchasing used foreign equipment each period and nothing at all; $\theta_{y u}$ as the preference of the buyer who is on the margin of choice between buying used US and used foreign equipment each period; $\theta_{c u}$ as the marginal consumer indifferent between buying used US equipment each period versus buying and keeping new US equipment every two periods; and $\theta_{n}$ as the consumer who is indifferent between buying and keeping new US equipment and buying new US or foreign equipment each period. By standard self-selection arguments described in Hendel and Lizzeri (1999), $\theta_{y f}<\theta_{y u}<\theta_{c u}<\theta_{n}$ and the following ICC's are satisfied: $V_{1}\left(\theta_{y f}\right)=0, \quad V_{1}\left(\theta_{y u}\right)=V_{2}\left(\theta_{y u}\right), \quad V_{2}\left(\theta_{c u}\right)=V_{3}\left(\theta_{c u}\right), \quad V_{3}\left(\theta_{n}\right)=V_{4}\left(\theta_{n}\right)$, and $V_{4}(\theta)=V_{5}(\theta)$ for $\forall \theta$. Additionally, the following market clearing conditions must be satisfied:

$$
\begin{aligned}
& y_{f}=\mathrm{F}\left(\theta_{y u}\right)-\mathrm{F}\left(\theta_{y f}\right), \\
& y_{u}=\mathrm{F}\left(0.5\left(\theta_{c u}+\theta_{n}\right)\right)-\mathrm{F}\left(\theta_{y u}\right),
\end{aligned}
$$

where $\mathrm{F}(\mathrm{)}$ ) is the CDF of $\theta$. The incentive compatibility constraints (ICC's), and the market clearing conditions, are sufficient to solve for the new and used prices of the equipment, as well as for the set of consumers that pursue each purchasing strategy.

Suppose that there is a quality-shock during the dispute resulting in a used US quality of $w_{u}^{\prime}<w_{u}$. Then, the change in the price of used US equipment is:

$$
\Delta P_{2 u} \equiv P_{2 u}^{\prime}-P_{2 u}=\theta_{y u}\left(w_{u}^{\prime}-w_{u}\right),
$$

where $P_{2 u}^{\prime}$ is the price of used US equipment produced during the dispute. The observed change in the US-foreign price differential can be interpreted as the change in service flow for the consumer who is on the margin of choice between buying used foreign equipment each period and buying used US equipment each period. This change is lower than the change in service flow to the average consumer who purchases used US goods since $\theta_{y u}<E\left[\theta \mid \theta \in\left(\theta_{y u}, \theta_{c u}^{\prime}\right)\right]$.

For purposes of identification, however, the problem is more complicated than simply allowing for a change in the quality of US equipment because the dispute could have also coincided with other changes in the market for construction equipment. Market-level demand- and supply-shocks are two 
possible confounding factors. For example, suppose that in addition to a quality shock, the dispute coincides with a change in the distribution of the $\theta$ 's, whereby each consumer's valuation of equipment changes proportionately by a factor $\rho(\rho>0)$. This change in the distribution of the $\theta$ 's could come about from changes in the value of the outside option. Following this demand shock, the consumer that is indifferent between used US and used foreign equipment will have a different valuation of equipment, $\theta_{y u}^{\prime}$, than in (8). A second possible confounder has to do with supply. I estimate that the dispute period was associated with about a $12 \%$ reduction in the quantity of equipment produced within US production lines relative to foreign lines, possibly coming about from production cuts due to a lack of workers, or the UAW's work-to-rule campaign. ${ }^{13}$ Lower US supply may lead to a higher resale price of US equipment in spite of a quality-shock. In terms of the model, suppose that during the dispute US production falls from $y_{u}$ to $y_{u}^{\prime \prime}\left(y_{u}>y_{u}^{\prime \prime}\right)$. The consumer that is indifferent between purchasing used US and used foreign equipment then rises from $\theta_{y u}$ to some value $\theta_{y u}^{\prime \prime}\left(\theta_{y u}<\theta_{y u}^{\prime \prime}\right)$.

Both the supply- and demand-shock examples lead to the same expression for the change in the US price. Using the notation from the supply-shock case, the change in US resale price becomes:

$$
\Delta P_{2 u}=\theta_{y u}^{\prime \prime}\left(w_{u}^{\prime}-w_{u}\right)+\left(\theta_{y u}-\theta_{y u}^{\prime \prime}\right)\left(w_{f}-w_{u}\right)+\left(\theta_{y f}^{\prime \prime}-\theta_{y f}\right) w_{f} \cdot{ }^{14}
$$

For the purpose of evaluating the economic implications of the quality-shock, the quantity of interest is $\theta_{y u}^{\prime \prime}\left(w_{u}^{\prime}-w_{u}\right)$, which can be interpreted as a change in service flows for the marginal consumer. The term $\left(\theta_{y u}-\theta_{y u}^{\prime \prime}\right)\left(w_{f}-w_{u}\right)$ will be small provided that US and foreign equipment are initially close substitutes, that is, if $w_{f}-w_{u}$ is small. By contrast, the term $\left(\theta_{y f}^{\prime \prime}-\theta_{y f}\right) w_{f}$ is potentially large and will hinder one's ability to isolate the change in service flows coming about from the quality shock.

The possibility of market-level shocks coinciding with a change in US equipment quality is why it is important to consider the difference-in-difference in price, namely the change in the US-foreign price differential over time. Again using the notation from the supply-shock example, computing the change in price for foreign equipment yields:

\footnotetext{
${ }^{13}$ A description of the procedure used to estimate production is in Appendix A.

${ }^{14}$ In the demand-shock example, the change in the price of US goods can then be written just as in (9), replacing $\theta_{y u}^{\prime \prime}$ with $\theta_{y u}^{\prime}$.
} 


$$
\Delta P_{2 f} \equiv P_{2 f}^{\prime \prime}-P_{2 f}=\left(\theta_{y f}^{\prime \prime}-\theta_{y f}\right) w_{f}
$$

The difference-in-difference expression is then:

$$
\Delta \Delta P_{2} \equiv \Delta P_{2 u}-\Delta P_{2 f}=\theta_{y u}^{\prime \prime}\left(w_{u}^{\prime}-w_{u}\right)+\left(\theta_{y u}-\theta_{y u}^{\prime \prime}\right)\left(w_{f}-w_{u}\right) .
$$

Note that the term $\left(\theta_{y f}^{\prime \prime}-\theta_{y f}\right) w_{f}$ has been differenced out from (10). If initially US and foreign goods are perfect substitutes $\left(w_{f}=w_{u}\right)$, demand- or supply-shocks will affect the price of both US and foreign equipment, but will not affect the gap between these prices. Therefore, by comparing the change of US and foreign equipment one can isolate factors that only affected changes in demand for US equipment within a market.

If new US and foreign equipment are imperfect substitutes prior to the dispute, then the second term of (10) is non-zero and the difference-in-difference in resale price will capture a combination of the downward shift in US equipment prices due to lower quality, as well the effects of the market-shock, which differentially affects the price of US and foreign equipment. In the supply-shock example, imperfect substitutability makes the identification of the price effect from negative quality changes due to the labor dispute more difficult to detect. It is an open but testable question as to whether consumers perceived US and foreign equipment to be close substitutes within model and production year classes. To determine this one can verify whether US equipment garnered a premium in the resale market relative to similar foreign-made equipment during the non-dispute period. I will ultimately conclude that the term $\left(\theta_{y u}-\theta_{y u}^{\prime \prime}\right)\left(w_{f}-w_{u}\right)$ is likely small.

A second prediction of the model is that the negative shock to US used equipment quality will decrease new prices, but accelerate price depreciation of US goods relative to foreign goods. To see why, note that (5), and the ICC's, imply that the rental price of US and foreign equipment are equal:

$$
P_{1 u}-\delta P_{2 u}=P_{1 f}-\delta P_{2 f} .
$$

A change in the quality of US equipment will not affect condition (11). Consequently, following the quality shock, consumers discount new US equipment relative to new foreign equipment such that the rental price of US equipment relative to foreign equipment is unaffected (both US and foreign rental prices decline). The difference-in-difference in the price of new equipment is therefore:

$$
\Delta \Delta P_{1} \equiv\left(P_{1 u}^{\prime}-P_{1 f}^{\prime}\right)-\left(P_{1 u}-P_{1 f}\right)=\delta \Delta \Delta P_{2} .
$$


Because the effect of a quality-shock on new prices is smaller than on resale prices, price depreciation of US goods will increase relative to that of foreign goods. While the structure of the resale data does not permit for clean tests for whether price depreciation of US goods accelerated, I can use data on list prices to examine the dispute's effect on prices in the new construction equipment market and compare this quantity with the resale market price effects. The model's prediction is that if there is a decline in used US equipment quality, list prices of US goods should decline relative to foreign goods, but these effects will be smaller than those seen in the resale market.

As a third and final prediction, I consider the size of the resale market for US equipment following the quality-shock. Defining $\mathrm{VOT}_{o}$ as the volume of trade in the resale market for equipment produced in country $o$, and assuming that $\theta \sim \mathrm{U}[\underline{\theta}, \bar{\theta}]$, the model implies that:

$$
\begin{aligned}
\Delta \Delta \mathrm{VOT} \equiv & \equiv \mathrm{VOT}_{u}-\Delta \mathrm{VOT}_{f}=\left(\mathrm{F}\left(\theta_{c u}^{\prime}\right)-\mathrm{F}\left(\theta_{y u}^{\prime}\right)\right)-\left(\mathrm{F}\left(\theta_{c u}\right)-\mathrm{F}\left(\theta_{y u}\right)\right) \\
& =(T(1+\delta) / 2)\left(w_{u}-w_{u}^{\prime}\right) / \delta\left(v-w_{u}\right)\left(v-w_{u}^{\prime}\right)>0,
\end{aligned}
$$

where $\theta_{c u}^{\prime}$ and $\theta_{y u}^{\prime}$ denote post-shock marginal consumers. ${ }^{15}$ Under the maintained assumptions, the size of the resale market for US equipment will grow following the downward shock to US quality. The change in the relative size of the US resale market only reflects the change in the US resale market since the volume of trade in foreign equipment is always $100 \%$. This feature of the model is validated by the empirical results which show that foreign goods are sold considerably more frequently at auction than comparable US goods, conditional on observable characteristics.

Note that the assumption of deterministic and observable quality rules out adverse selection in the resale market. An alternative approach is to allow second period quality to be random and unobserved by buyers, thus allowing for adverse selection. ${ }^{16}$ In this scenario, consumers of new US equipment will keep a good with a sufficiently high quality realization. The predictions for used prices following a quality shock will be the same in both the model already outlined. However, as Hendel and Lizzeri (1999) note, the prediction on the volume of trade in the resale market will depend on the exact nature of quality realizations. In the deterministic case already discussed, volume is predicted to rise. In the alternative case, where a quality-shock is modeled as a mean preserving spread to the distribution of US equipment

\footnotetext{
${ }^{15}$ The uniform distribution is assumed for tractability. Other distributions also give this result.
} 
quality, adverse selection will lead to a smaller resale market in US equipment, as is standard in these kinds of models. Ultimately, the question is an empirical one: if prices and condition reports indicate that the dispute-era US equipment were of lower quality, examining volume of trade will allow one to determine whether the quality shock resulted in adverse selection, or whether it was characterized by general and observable depreciation.

\section{Estimation}

Equation (9) suggests that an estimate of $\Delta \Delta P_{2}$ can be interpreted as the change in service flows of equipment produced in US plants during the dispute for the marginal consumer, with an additional term accounting for the effects of potential market-wide shocks on the relative price of US and foreign goods. The purpose of this section is to describe how I will estimate this quantity.

The first step towards reconciling the model with the data is to recognize that the resale market for construction equipment is characterized by a large number of models and vintages, while the theoretical model is specified for a single market. It is therefore necessary to make comparisons within narrowly defined classes of equipment that approximate a market. I define a market (which I will also call a cohort) as equipment belonging to the same model-class, production year, and calendar year of auction. ${ }^{17}$ For example, the set of 1992-era 690B Caterpillar wheel dozers which were sold at auction in 1997 constitutes one market. The primary reason for making comparisons within markets is to adequately control for market-wide shocks. For example, markets that are dominated by US-made equipment could experience higher prices, in spite of a potential quality-shock, because of relative scarcity of dispute-era US equipment. Within markets, however, the price effects of a supply-shock will be less of a confounder because it affects the prices of both US and foreign goods.

Because of substantial heterogeneity in price-levels across models, I will estimate the price models in logarithms. By modeling the changes as proportional, I allow for a consumer's willingness to pay to pay to avoid defective machines to be a function of the baseline cost of the machine. This specification is sensible because there is an opportunity cost associated with the use of equipment; the capital invested in equipment undergoing maintenance could be invested elsewhere. By contrast, modeling changes in the

\footnotetext{
${ }^{16}$ Genesove (1993) finds only weak evidence of adverse selection in the wholesale used car market.
} 
US-foreign price differential in levels would imply that customers are willing to pay a fixed amount to ensure that the equipment is not defective. ${ }^{18}$

In order to visually display the time-path of the US-foreign price differential, I will first estimate a model where the US price premium is allowed to vary across production years:

$$
\operatorname{lnp}_{i c}=\alpha+\beta^{\prime} \mathrm{X}+\gamma_{c}+\delta_{\tau} \mathrm{Y}(\tau) \times U S_{i}+h\left(\pi_{a t \tau}\right)+\varepsilon_{i c}, \tau=1984-2000 .
$$

$\ln \mathrm{p}_{i c}$ denotes the $\log$ price in 2000 dollars of equipment $i$ from cohort $c$ (model $\times$ production year $\times$ auction year), $\gamma_{c}$ is a cohort fixed-effect, $\mathrm{US}_{i}$ takes the value of 1 if equipment is produced in the US and 0 otherwise, and $Y(\tau)$ takes the value of 1 if the equipment is produced in year $\tau$ and 0 otherwise. The vector of covariates $\mathrm{X}$ contains region of auction dummies, month of auction dummies, age of production line, and the number of years that the equipment was held in inventory by Caterpillar. ${ }^{19}$ The variable $\pi_{\text {at }}$ denotes the proportion of equipment produced on assembly line $a$ in year $\tau$ that are sold at auction in year $t$. $h(\cdot)$ is a selectivity adjustment that depends on $\pi_{a t \tau}{ }^{20}$ The adjustment is included because of the possibility that goods reaching the resale market are not representative of the population, perhaps due to transaction costs or asymmetric information. In such cases, the optimal selling rule for consumers is determined by cut-off functions, whereby consumers sell equipment if their quality is below some

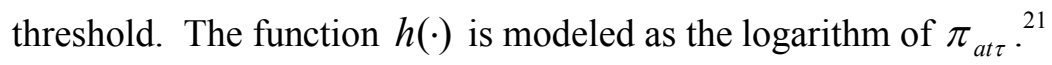

The parameters of interest $\left(\delta_{1984}-\delta_{2000}\right)$ represent the US-foreign log price differential for each year of production and are identified from variation in country of origin of assembly lines within model-

\footnotetext{
${ }^{17}$ Ideally, I would also make comparisons of equipment within auctions. However, there are not sufficient data to make these comparisons reliably.

${ }^{18}$ Estimates are qualitatively similar when estimating the models in levels. Tables are available upon request.

${ }^{19}$ While information on the market to which the equipment was originally shipped is not available, the region in which equipment was resold at auction is. States or countries of auction are collapsed into the following seven regions: Pacific and Mountain Census regions; West North Central, West South Central and East North Central Census regions; South Atlantic, Middle Atlantic and New England Census regions; Asia and Australia; Mexico; Canada; and Europe. The results are robust to finer groupings of states and countries.

${ }^{20}$ The function $h()$ is an approximation to the selectivity adjustment of an arbitrary model of auction market participation in which participation depends on a single index that is fully absorbed by assembly-line $\times$ production year $\times$ auction year dummies (Ahn and Powell 1993; Card and Payne 1997). While I find some evidence of nonrandom selection into the sample, the results are robust to the exclusion of the selectivity function as well as to varying specifications of the function $\mathrm{h}($ ).

${ }^{21}$ Because the data span production year 1984-2000, there is no need to include a US main-effect in this model, as it would be collinear with the production year and country of origin interactions. Also, this model does not explicitly have year effects because they are absorbed by the cohort effects.
} 
classes. Because of the presence of cohort effects, these parameters are only identified from models that are produced both in the US and abroad. Consequently, in specifications that include cohort effects, I limit the sample to such models. Of the 353 models represented in the sample, $23 \%$ have production lines both in the US and abroad. These production lines account for $40 \%$ of the equipment in the sample.

Model (14) is flexible and fully accounts for heterogeneity across calendar year, production year, models, as well as their interactions. Comparing equipment within model-classes ensures that the estimates are not driven by changes in the composition of US and foreign equipment over time. The region dummies ensure, among other things, that the estimated US-foreign price differentials are not driven by changes in distribution patterns of US and foreign equipment, as could be the case if production patterns changed during the dispute. These regional differences could matter because used US and foreign equipment may be systematically different if they are distributed to regional markets with different demands for optional characteristics, or if the equipment is exposed to different climatic conditions.

After examining the US-foreign log price differential across individual production years, I then estimate the average difference in the US-foreign log price differential between the dispute and the nondispute periods:

$$
\ln p_{i c}=\alpha+\beta^{\prime} \mathrm{X}+\gamma_{c}+\varphi \mathrm{US}_{i}+\phi \mathrm{US}_{i} \times \mathrm{DISPUTE}_{i}+h\left(\pi_{a t \tau}\right)+\varepsilon_{i c}
$$

DISPUTE $_{i}$ is a dummy variable equal to 1 if the equipment is produced during the period of the dispute. $^{22}$ The parameter $\phi$ is approximately a weighted average of $\Delta \Delta P_{2} / P_{2 u}$ across model-classes, where $P_{2 u}$ is the baseline (non-dispute) price of US equipment in a given model-class, and $\Delta \Delta P_{2}$ is as given by equation (10). If US and foreign equipment are reasonably close substitutes in the non-dispute period, or if there were no significant supply- or demand-shocks during this period, then: $\Delta \Delta P_{2} \approx \theta_{y u}^{\prime \prime}\left(w_{u}^{\prime}-w_{u}\right)$, which has an interpretation as a change in service flows for the marginal consumer. I can then use an of estimate $P_{2 u}$ to back out this term from $\Delta \Delta P_{2}$. Because of the supply-shock that affected US plants during the dispute, and because US and foreign equipment are not perfect substitutes,

\footnotetext{
22 The dispute period is defined as the period spanning mid-1991 to early 1998. I consider 1991 a dispute year and 1998 a non-dispute year, but estimates are robust to alternative definitions.
} 
$\left(\theta_{y u}-\theta_{y u}^{\prime \prime}\right)\left(w_{f}-w_{u}\right)$ is likely to be positive (but small). Under these conditions, $\hat{\phi}$ will somewhat underestimate the effect of a quality-shock on prices.

For reference, I also estimate a baseline model which uses all of the data, but does not include cohort effects and is therefore less flexible:

$$
\operatorname{lnp}_{i m t}=\alpha+\gamma_{m}+\eta_{t}+\beta_{1} \mathrm{Age}_{i}+\beta_{2} \mathrm{Age}_{i}^{2}+\varphi \mathrm{US}_{i}+\kappa \operatorname{DISPUTE}_{i}+\phi \mathrm{US}_{i} \times \operatorname{DISPUTE}_{i}+\varepsilon_{i m} .
$$

Specification (16) includes model fixed-effects $\left(\gamma_{m}\right)$, as well as a quadratic polynomial in age, and auction year dummies $\left(\eta_{t}\right)$. The disadvantage of this model is that the estimate of $\phi$ will pick up the residual effect of vintage-level variation in price resulting from market-level shocks that disproportionately affect US goods, for example, US production cuts. This problem is not as serious when using cohort effects because, within a market, these shocks will affect the prices of both US and foreign machines.

The last two outcomes I will consider are volume of trade and list prices. I will outline the statistical models used to test these predictions when discussing the data utilized in these analyses.

\subsection{The Effect of Labor Unrest on Appraisals}

I will begin by testing how the labor dispute affected the physical condition of the construction equipment using condition reports (appraisals) from Equipment Watch data collectors. I then analyze resale prices to investigate the effect of the dispute on the economic quality of equipment. Estimating the effect of the labor dispute on resale prices is more challenging than measuring the effect of the dispute on quality appraisals because resale prices are determined by many factors that do not necessarily affect the physical quality of equipment, including market conditions, consumer tastes and market structure. For this reason, and for purposes of comparability, the statistical models employed will be the same as those used for the price outcome, described in equations (14)-(16).

The physical condition outcome consists of six categories, ranging from "poor" to" excellent". 23 Table 1 reports the proportion of equipment belonging to each category. A majority of the $79 \%$ of equipment with a reported condition falls in two categories: "good" or "very good". The next most frequently reported category is "fair", with $8.6 \%$ of the reported conditions. The ordered nature of the

\footnotetext{
${ }^{23}$ The six condition categories are poor, fair, good, very good, excellent and new. Because I am interested in resale outcomes, I discard 106 pieces of new equipment sold at auction that appear in the sample.
} 
appraisals data suggests the use of an ordered probit model to estimate the effects of the labor dispute on quality. A drawback to the ordered probit model, however, is that it is not well-suited to a fixed-effects strategy. Unlike some other non-linear models with categorical outcomes, an ordered logit or probit model that conditions-out fixed-effects using a minimum sufficient statistic has not been developed. ${ }^{24}$ For this reason, I will first present specifications using a "monetized condition index" (MCI) as an outcome. This index weights the condition categories by their impact on price. Concretely, the index is constructed by regressing log transaction prices on dummy variables for each condition category, including a unknown category, a set of other covariates, and cohort fixed-effects. ${ }^{25}$ The estimated coefficients from the six condition dummies multiplied by 100 are used as the values for the index. I normalize the index so that equipment appraised as poor takes on the value of 0 , with the remaining condition categories valued relative to poor equipment. Appendix Table 1 reports the values of the index for the five categories, as well as the standard errors for the coefficients, with $R^{2}$ corresponding to the regression used to estimate the index. The mapping of the condition index to the condition categories appears reasonable-better condition categories correspond to higher average prices at auction.

I begin by examining the regression adjusted US-foreign monetary condition index differential by individual production year. These are estimated by fitting equation (14) to the data, but using the MCI as the dependent variable instead of log price. Figure 3, which plots $\hat{\delta}_{1984}$ through $\hat{\delta}_{2000}$, shows a dip in the regression-adjusted US-foreign monetary condition index differential during the period when the Caterpillar UAW workers did not have a contract. The figure reveals that US- and foreign-made equipment received similar appraisal reports before 1989, followed by a relative improvement in the condition of US equipment produced in 1989 and 1990. In 1991, the first year of the dispute, the USforeign MCI differential fell sharply, and remained low until 1998, when it reverted to pre-dispute levels.

Table 2 quantifies the average change in the US-foreign MCI differential from the non-dispute period to the dispute period. Estimates from the baseline model (16) using the MC outcome are presented in column (1). The model shows in an estimated US-dispute interaction of -0.21 , with a t-ratio of -2.33 . The US-dispute period is associated with about a one fifth of a percent reduction in resale prices of US-

\footnotetext{
${ }^{24}$ A second disadvantage to this model is that it requires discarding equipment with unknown category ratings.

${ }^{25}$ A description of the construction of this index is available in Appendix B.
} 
made equipment via the change in condition categories, an effect that is small in magnitude, but estimated precisely. Columns (2)-(6) present results from specifications that are variants of equation (15), and employ model $\times$ production year $\times$ auction year (cohort) fixed-effects, again using the MCI as the dependent variable. In each of these specifications, the US-dispute interaction is negative and statistically significant at conventional levels. In column (2), for example, the estimated effect is -0.59 with a t-ratio of 5.4. This estimate is robust to the introduction of additional controls, including the region of auction, production-line age, time in inventory, and a selectivity adjustment (column 3). The interaction term grows in magnitude when a US $\times$ production year trend is introduced in column (4). Columns (5) and (6) show that estimates of the US-dispute interaction are robust to whether the comparison made is predispute/dispute or dispute/post-dispute. These results are consistent with the pattern observed in Figure 3, where the US-premium before and after the dispute have similar magnitudes.

Additional noteworthy features of Table 4 are the estimated coefficients on the US-main effect and the age of the production-line at the time of the equipment's production. The estimated US maineffect is positive and significant in all but one models, indicating that US equipment produced in the nondispute years was in somewhat better physical condition than foreign equipment once it appeared in the resale market, even after controlling for region of sale and other factors. Equipment produced on older production lines was in better condition once they reach the resale market (column 3), an effect that is statistically significant at the $5 \%$ level, suggesting that learning-by-doing may play a factor in the quality of construction equipment. ${ }^{26}$

Table 3 shows that the finding that appraisal ratings decline among dispute-affected equipment is not an artifact of the construction of the monetary condition index. This table presents results from ordered probit models, using the equipment appraisal as the dependent variable. As already noted, the ordered probit model is not suited for fixed-effects estimation. Therefore, the parameters in this model are not identified by comparisons of US and foreign equipment within cohorts over time. Rather, I include a relatively parsimonious set of covariates. ${ }^{27}$ Because cohort effects are not included I include transactions in models that were produced exclusively in the US or abroad. The estimates from the ordered probit

\footnotetext{
${ }^{26}$ This result that may be considered in contrast to Thompson (2001) who finds a tradeoff between the age of the production line and quality of World War II era Liberty Ships.
} 
models show a statistically significant downward shift in the physical quality of the equipment in the dispute period. For example, looking at the marginal effects, US equipment produced during the dispute were associated with declines in the probability of being rates "excellent" or "very good."

\subsection{The Effect of Labor Unrest on Resale Prices}

Appraisal reports provide evidence that the physical quality of US-made equipment declined relative to foreign-made equipment at the time of the dispute. I now consider whether the dispute affected the economic quality of the construction equipment. Figure 4 plots the regression-adjusted US-foreign $\log$ price differential for each production year, obtained by estimating model (14). The figure is striking in its similarity to Figure 3. In both figures, the series trend upwards prior to the dispute, drop during production year 1991, and revert back to pre-dispute levels around 1998. The figure shows that equipment made in the US in 1990 sold at almost a 4\% premium relative to comparable foreign equipment from the same production year, whereas US equipment from the 1991 vintage sold at a $2 \%$ discount. $^{28}$ This discount persisted through most of the dispute-era vintages, with the exception of 1997-the last full year of the dispute-when the US-foreign resale price differential reverted back to pre-dispute levels.

Table 4 presents estimates of the difference in the US-foreign log price differential between the dispute period and the non-dispute period. The baseline specification in column (1) presents estimates obtained by fitting (16) to the data. The US-dispute coefficient is estimated as $0.011(\mathrm{t}=0.85)$. Evidently, the baseline model does not reveal much of a change in the US-foreign price differential following the dispute and, if anything, it shows that the change is positive. However, the sign on the estimated USdispute coefficient reverses when model (15) is estimated. Using this more flexible model, with cohort fixed-effects, it appears that machines produced in an environment of labor strife are discounted by the resale market. In column (4), for example, the estimated coefficient on the US-dispute interaction variable is -0.054 , with a t-ratio of 3 , implying that the US-foreign resale price differential was approximately $5.5 \%$ higher for equipment produced in non-dispute vintages than dispute vintages. ${ }^{29}$ The reversal in sign on the

\footnotetext{
${ }^{27}$ The covariates in Table 3 are a quadratic polynomial in age, twenty equipment class dummies (broad equipment groupings), auction year dummies, years in inventory, and production line age.

${ }^{28}$ It is not surprising that such a large break in the US-foreign price differential would be observed in 1991. Negotiations had been in progress since at least July and, as discussed in Section II, there were signs that workers knew the company would take a hard line as early as 1990.

${ }^{29}$ The estimated 5.5\% discount is essentially a "reduced-form" estimate of the effect of the labor dispute on the value of equipment. This is because the comparison being made is between US and foreign products, and not all plants in
} 
estimated US-dispute interaction from the baseline model to models with cohort fixed-effects suggests that it is important to account for market-wide shocks, such as the US production cuts, via inclusion of these fixed-effects. Consistent with this interpretation, we do not see this reversal when using the appraisal outcome, which is to be expected because such demand- and supply-shocks should not directly affect appraisal reports, while they should affect resale prices.

The estimated US-dispute interaction coefficient is robust to the inclusion of additional controls. The selectivity adjustment, while generally significant, does not greatly affect the estimates via its inclusion. The estimate is also robust to controlling for the number of years the equipment was held by Caterpillar in inventory, age of the production lines at the time equipment was produced, and a US $\times$ production year trend, which allows for differential trends in resale prices for US- and foreign-made equipment by vintage. Another robustness check is that the estimated US-dispute discount rate be of the same order of magnitude when making a pre-dispute/dispute versus dispute/post-dispute comparison. Indeed, comparing the US-dispute estimates in columns (5) and (6) reveals that they are both negative, though larger in magnitude in the dispute/post-dispute comparison. These results show that the premium US produced equipment enjoyed before 1991, and after 1997, virtually disappeared during the dispute. The dispute period is associated with a substantially larger discount of US equipment than would be implied by the change in the condition categories alone. This comparison is made explicit in column (7) where the condition categories are included as controls. Comparing columns (7) and (3), one can see that the inclusion of the condition category dummies has only a marginal effect on the estimated US-dispute interaction. Consumers appear to be more sensitive to quality differences than the independent appraisers.

As an additional specification, I use the fact that some Caterpillar equipment contained engines produced by other manufactures. Approximately $23 \%$ of the equipment in the sample contained engines that were outsourced, primarily from Perkins Engines. ${ }^{30,31}$ I can test whether resale prices of Caterpillar equipment produced in the US during the dispute containing engines produced by other manufactures

the US were subject to the labor dispute. As noted earlier, approximately $87 \%$ of employment in the US took place in unionized plants. While I do not have information on the percent of equipment produced in unionized plants, using the $87 \%$ figure would imply that the dispute was associated with a $6.3 \%$ discount on US equipment, once the coefficient has been rescaled.

${ }^{30}$ In December 1997 Caterpillar purchased Perkins Engines.

${ }^{31}$ Model and production year of equipment was matched to information from the Equipment Watch's Green Guide to obtain the manufacturer of its engine. 
behaved differently than dispute-affected equipment with Caterpillar engines. If one of the reasons for discounting machines produced during labor unrest is that engines were of inferior quality, then equipment produced in the US during the dispute containing engines produced by other manufacturers should receive less of a discount than equipment with Caterpillar engines.

Table 5 presents the results of the log resale price model for equipment with and without Caterpillar engines. The estimated US-dispute interaction is estimated at $-0.037(\mathrm{t}-=3.1)$ for machines whose engines are produced in-house versus $-0.011(\mathrm{t}=0.42)$ for machines whose engines are outsourced. While the estimated coefficient is more than twice as large for equipment containing Caterpillar engines as compared to machines equipped with other manufacturer's engines, the difference between the estimates is not statistically significant at conventional levels. ${ }^{32}$

\subsection{Assessing the magnitude of possible biases from market-level shocks}

The positive and statistically significant coefficients on the US main-effect in Table 4 suggest that, before and after the dispute, pieces of US- and foreign-made equipment were not perfect substitutes, even within the narrow markets considered in this paper. ${ }^{33}$ Recalling equation (10), market-level shocks will affect the relative price of US and foreign used equipment if they are imperfect substitutes in the nondispute period. Using the theoretical model, I conduct a simple calibration to determine the sensitivity of the US-foreign price differential to market-level shocks given the estimates in Table 3.

Equation (10) implies that in a given market:

$$
\Delta \Delta \ln P_{2} \approx \theta_{y u}^{\prime \prime}\left(w_{u}^{\prime}-w_{u}\right) / P_{2 u}+\left(\theta_{y u}-\theta_{y u}^{\prime \prime}\right)\left(w_{f}-w_{u}\right) / P_{2 u} \cdot{ }^{34}
$$

The quantity of interest is $\theta_{y u}^{\prime}\left(w_{u}^{\prime}-w_{u}\right) / P_{2 u}$, while the second term captures how a market-level shock, which shifts the marginal consumer from $\theta_{y u}$ to $\theta_{y u}^{\prime \prime}$, affects the relative price of US and foreign equipment. For the sake of argument, suppose that the dispute was not associated with a quality-shock $\left(w_{u}=w_{u}^{\prime}\right)$, and that the negatively estimated US-dispute interaction is coming about entirely from a

\footnotetext{
${ }^{32}$ Imprecision may stem in part from the prevalence of rebuilt engines in used construction equipment.

${ }^{33}$ Explanations for this premium include the possibility that consumers discounted foreign equipment because they could not determine whether the equipment was one of a small number of equipment not intended for sale in the US, and because it may not pass EPA emission standards, or simply that US-made machinery was better made than foreign machinery in non-dispute years.

${ }^{34}$ For the sake of parsimony I will consider a single market. The analysis extends to the average of many markets.
} 
market-level demand-shock that shifted the marginal consumer from $\theta_{y u}$ to $\theta_{y u}^{\prime \prime}\left(\theta_{y u}^{\prime \prime}<\theta_{y u}\right)$. The estimated US-foreign $\log$ price differential of $4 \%$ in the non-dispute period implies that the marginal consumer's willingness to pay for equipment would have had to have fallen by a factor of four in order to generate the observed change in the US-foreign price differential of $5 \%{ }^{35}$ Given that total factor productivity (TFP) in the construction equipment industry was stable, and Caterpillar's profit was rising, it is unlikely that there was such an extreme shift in demand for Caterpillar equipment during this period. ${ }^{36}$

As already discussed, there were changes on the supply-side of the market. The dispute was associated with approximately a $12 \%$ reduction in the production of US goods relative to foreign goods. This supply-shift implies that the stock of machines in the market would have fallen by at most $6 \%$ in steady-state. ${ }^{37}$ The US main-effect implies that $\left(\left(w_{u}-w_{f}\right) / P_{2 u}\right) \theta_{y u} \approx 0.04$. Assuming that $\theta \sim \mathrm{U}(\underline{\theta}, \bar{\theta})$, following a $6 \%$ reduction in the stock, the marginal consumer becomes:

$$
\begin{aligned}
\theta_{y u}^{\prime \prime} & =0.94 \theta_{y f}+.06 \bar{\theta}+y_{f}(\bar{\theta}-\underline{\theta})<\theta_{y f}+.06 \bar{\theta}+y_{f}(\bar{\theta}-\underline{\theta})=\theta_{y u}+0.06 \bar{\theta} \\
& \Rightarrow\left(\left(w_{u}-w_{f}\right) / P_{2 u}\right) \theta_{y u}^{\prime \prime}<0.04+.06\left(\left(w_{u}-w_{f}\right) / P_{2 u}\right) \bar{\theta} .
\end{aligned}
$$

In order to assess the magnitude of the bias term in (17), it is necessary to make an assumption about $\bar{\theta}$ 's willingness to pay relative to $\theta_{y u}$. In this context, it is reasonable to assume that heterogeneity in consumer willingness to pay for equipment comes about from productivity differences. Using plant-level data from the Census of Manufacturers, Syverson (2004) estimates that within 4-digit SIC industry, the $95^{\text {th }}$ percentile of TFP is approximately four times as large as the $5^{\text {th }}$ percentile, on average. Assuming that the ratio in willingness to pay between $\bar{\theta}$ and $\theta_{y u}$ consumers is approximately 4-1 we obtain:

$$
\left(\left(w_{u}-w_{f}\right) / P_{2 u}\right) \theta_{y u}^{\prime \prime}<.04+.06\left(\left(w_{u}-w_{f}\right) / P_{2 u}\right) \bar{\theta}=.04+.06\left(\left(w_{u}-w_{f}\right) / P_{2 u}\right) 4 \theta_{y u}=0.0496 .
$$

\footnotetext{
${ }^{35}$ To see why, note that $\theta_{y u}\left(w_{f}-w_{u}\right) / P_{2 u} \approx-.04$. In order for $\Delta \Delta \ln p \approx-.05$ - the magnitude of the estimated USdispute interaction - the term $\theta_{y u}^{\prime \prime}\left(w_{f}-w_{u}\right) / P_{2 u}$ would have to be approximately -0.01 , implying that $\theta_{y u}^{\prime \prime}=\theta_{y u} / 4$. ${ }^{36}$ TFP in the construction industry grew by $0.39 \%$ between $1990-1995$, and fell by $1 \%$ between 1995 and 2000 (Fernald and Ramnath 2004).

${ }^{37}$ There is a $6 \%$ reduction in stock if Caterpillar's foreign plants did not increase production in response to US production cuts, there were no other competitors in this market, and the US market share was $50 \%$. If increased production from foreign plants directly offset reduced US production, then the marginal consumer $\theta_{y u}$ would not change, and the production-shock would not have affected the relative price of used US and foreign equipment.
} 
Referring back to equation (17), the component of the difference-in-difference in log price that is attributable to the production-cuts is then bounded between 0 and 0.01 , or less than one percentage point. ${ }^{38}$

Using the estimated US premium in the non-dispute period, and plausible estimates for the degree of variability in TFP distribution in this market, I conclude through this simple calibration exercise that the supply-shock should only have a small positive effect on the change in the US-foreign log price differential given the non-dispute US premium. ${ }^{39}$ Moreover, market-level demand-shocks would have had to have been extraordinarily large in order to account for the observed difference-in-difference in $\log$ price. Therefore, I conclude that the US-dispute interaction primarily reflects shifts in demand for equipment of US origin. As I have ruled out many alternative explanations for the changing US-foreign price differential in the statistical model, I interpret the US-dispute interaction as primarily reflecting a change in service-flows for dispute-affected equipment.

\subsection{The Effect of Labor Unrest on Resale Rates}

Equation (13) from the theoretical model implies that worsening equipment quality should lead to higher resale rates. However, as discussed, the prediction for resale rates is ultimately ambiguous because a variant of the model, which allows for the quality-shock to increase the variance in quality will lead to the opposite prediction when there is asymmetric information. The effect of the dispute on the resale rate of affected equipment can therefore shed light on the precise nature of the quality shock and how it manifested itself in the market.

To test for the effect of the quality-shock on the volume of trade one can compare the volume of trade for US versus foreign equipment, holding constant relevant factors. However, this approach is problematic: while detailed assembly line level production data are available, data on exports and imports are not. Since most of the auctions considered in this paper occur in the US, changes in the number of goods exported would result in changes in the estimated US-foreign differential in volume of trade, even if the relative resale rates for US and foreign equipment were to remain unchanged.

An alternative measure of the resale rate is whether a piece of equipment has been resold in the auction market conditional on appearing in the US resale market. The sample size is large enough that

\footnotetext{
${ }^{38}$ This bound is obtained by noting that: $0<\left(\left(w_{u}-w_{f}\right) / P_{2 u}\right) \theta_{y u}-\left(\left(w_{u}-w_{f}\right) / P_{2 u}\right) \theta_{y u}^{\prime \prime}<.0096$.
} 
individual pieces of equipment may appear multiple times as they are resold at auction. In fact, about $8.5 \%$ of the equipment was resold at least twice in the sample. This feature of the data can be exploited by constructing a measure of the equipment-specific resale rate. Specifically, the resale rate measure is defined as the number of units of equipment that were resold multiple times in production line $x$ production year $\times$ region groups.

To model the resale rate conditional on other variables, I employ count data regression models. I use a cell-level dataset where equipment characteristics are collapsed into production line $\times$ production year $\times$ region cells. The number of pieces of equipment that appear multiple times in each of these cells, $y_{\text {lm } \tau r}$, is modeled as:

$$
E\left[y_{l m t r} \mid \mathbf{x}_{l m \pi r}, \alpha_{m}\right]=\exp \left(\ln \left(\alpha_{m}\right)+\beta^{\prime} \mathrm{X}\right),
$$

where $\alpha_{m}$ represents model fixed-effects, $r$ denotes region of auction, and the $\mathrm{X}$-vector of explanatory variables contains the logarithm of the number of pieces of equipment sold in the production line $x$ production year $\times$ region group, production year dummies, region dummies, and production line vintage. ${ }^{40}$ Model (18) can be estimated using Poisson conditional maximum likelihood, conditioning on the count total $\sum_{\pi r} y_{l m \pi r}$ for each model. I compute robust standard errors that are consistent in the presence of over dispersion. $^{41}$

Table 6 presents conditional fixed-effect Poisson models for multiple sales in the sample (columns 2-5). For reference, columns (1) and (2) present estimates from the standard Poisson model without fixedeffects. $^{42}$ All of the specifications control for the log of the number of equipment that appeared in the auction resale market in a given cell. As expected, the estimated coefficient on this variable is estimated

\footnotetext{
${ }^{39}$ A distribution of consumer heterogeneity with substantial skew may lead to a larger bias term. However, this bias will necessarily be positive, which works against detecting a quality effect.

${ }^{40}$ In practice a more flexible set of fixed-effects may be used, for example interactions of model, production year, and region. Unfortunately, these specifications yield few observations per cell, which may lead to inconsistent estimates in a non-linear model such as the one I am estimating.

${ }^{41}$ The fixed-effects Poisson maximum likelihood estimator of $\beta$ is consistent if the conditional mean does not equal the conditional variance, if equation (18) is a correct specification, although the standard errors are inconsistent. I follow Wooldridge (1999) to compute standard errors that are robust to over-dispersion.

${ }^{42}$ To compute robust standard errors in the Poisson model I allow: $\operatorname{Var}\left(y_{\operatorname{lm}|l|} \mid \mathbf{x}_{\mathbf{i}}\right)=\alpha \exp \left(\mathbf{x}_{\mathbf{i}}{ }^{\prime} \beta\right), \alpha>1$, where $\alpha$ is an over dispersion parameter. The robust standard errors thus equal the usual Poisson standard errors multiplied by the square root of $\alpha$. I estimate $\alpha$ by: $\hat{\alpha}=(n-k)^{-1} \sum_{i=1}^{n}\left(y_{i}-\hat{y}_{i}\right)^{2} / \hat{y}_{i}$. See Cameron and Trivedi (1998; p. 63-65) on robust Poisson.
} 
close to unity. The models show that equipment produced in the US during the dispute period had a substantially higher resale rates than other equipment. In column (3), for example, the US-dispute interaction has a coefficient of 0.26 , with a t-ratio of 2 . To interpret the magnitude of the coefficient, note that $\exp (0.26)=1.3$, which implies that the incidence of multiple sales is $30 \%$ higher for equipment originating from US-based production lines during the labor dispute, other things held constant. The US main-effect is large and negative. In column (3) the US main-effect has a coefficient of $-0.38(\mathrm{t}=-3.5)$. One explanation for the negative US main-effect is that imported equipment tends to pass through more intermediaries before reaching final buyers. An alternative explanation is that the volume of trade in the resale market for US goods is lower in the non-dispute period because the quality of US goods is higher, as predicted by the theoretical model.

Column (4) makes the dispute/post-dispute comparison. In this model the US-dispute interaction has a coefficient of 0.23 , but is not statistically significant. The imprecision in this case is not surprising as equipment pieces from the relatively recent post-dispute vintages have not had time to reach the resale market in great numbers. The estimated US-dispute interaction in column (5), which makes the predispute/dispute comparison, is 0.24 , with a t-ratio of 1.9 . Large and positive estimates yielded by both the dispute/post-dispute and pre-dispute comparisons strengthens the evidence that the change in resale rates for US equipment occurred precisely for dispute-era vintages and that change is not the result of a differential trend between these two groups.

Higher resale rates of US equipment indicate that the dispute-era quality-shock was most likely not characterized by adverse selection, as that would have reduced the size of the resale market. Rather,

the evidence is consistent with worsening quality being observed by all parties in the market. According to this version of the model, volume of trade rose because consumers seeking to maintain a stable average quality of the equipment in their portfolio sold faster depreciating products more quickly.

\subsection{The Market for New Equipment}

The outcomes discussed in this paper all relate to resale market characteristics of the construction equipment in the sample. The theoretical model also predicts that a quality-shock will lead to a (small) decline in the price of new equipment. To test this prediction, I collected list prices for 180 models of 
Caterpillar equipment for the years 1992 through 2000 from the Equipment Watch Green Guide. ${ }^{43}$ Because list prices correspond to models, rather than to specific production lines, an estimation strategy employing comparisons between US and foreign equipment within model classes is not possible. Using the serial number guide previously described, I linked the models to the country of production. If Caterpillar (or the market) was aware of quality declines at its US plants during the dispute, model classes with a higher share of US-made equipment may have sold at discount relative to models with a larger share of foreign-made equipment.

For each model the fraction of equipment produced in the US was calculated by production year. This variable measures the vulnerability of each model-class vintage to the dispute. Column (1) of Table 8 presents results in which the fraction of equipment in a model class produced with the United States is interacted with a dispute period dummy. In column (2), I compare models exclusively produced in the US to models exclusively produced abroad. Both specifications include model fixed effects that hold constant both any changes Caterpillar may have made to its product mix in the period of the dispute, and year effects. In both of the specifications, the $R^{2}$ is extremely high, at 0.99 . Most of the variation across new equipment prices can be accounted for by permanent differences across models. Still, the estimates reveal significantly higher growth in list prices of models that have a larger share of US production in the post dispute period relative to the pre-dispute period. In column (2), for example, the list prices of USproduced models are estimated to be $1.8 \%$ larger than foreign-produced models after the dispute relative to the dispute period, with a corresponding t-ratio of 2.6.

Figure 5 plots the growth in list prices for models produced exclusively in the US relative to those produced exclusively abroad. ${ }^{44}$ The price of model classes produced exclusively in the US grew at about the same rate as model classes produced exclusively abroad between 1992 and 1998 but grew about 1.5\% faster than those produced abroad after 1998, when the dispute was over. Of course, the discussion in previous sections on the difficulty of obtaining estimates of the US-dispute interaction free of supply effects still applies and, in fact, in the new goods setting this confounder is even more serious than in the

\footnotetext{
${ }^{43}$ A disadvantage of using list prices is that, in practice, actual prices paid may differ from list prices because of discounts.

${ }^{44}$ The figure is obtained by estimating a model with the logarithm of model list price as the dependant variable, year of production dummies, and interactions of an indicator for whether the model was produced in the US with production year dummies. The estimated interaction terms are plotted in Figure 5.
} 
resale case. Because the list price data is not disaggregated by production-line, I cannot employ the same estimation strategy used in the resale market. Therefore, estimates for list prices may be viewed as underestimating the effects of the dispute on new prices, as the supply-shock should, in theory, lead to an upwards shift in the price of models dominated by US equipment.

Because the evidence suggests that new dispute-affected equipment was discounted, some of the costs due to the lower quality product were borne by Caterpillar and not by its consumers. Keeping in mind the possible upward bias in the US-dispute estimated due to reduced supply, the magnitude of the estimated US-dispute effect on list prices is broadly consistent with what is predicted by the theoretical model following a latent reduction in US quality-new US prices fell, but the reduction was smaller than the discounting seen in the resale market.

\section{Discussion}

On balance, the analysis of resale prices suggests that the equipment produced in facilities undergoing labor disputes was discounted by the resale market by about $5 \%$. This reduction in value may arise from a reduction in salvage value, reduced productivity of the equipment, increased operating expenses, or some combination of these three factors. If consumers knew the origin of equipment, which is likely because the serial number guide employed here is in the public domain, then discounting may have occurred because there was common knowledge that certain vintages of US equipment were of inferior quality. However, common knowledge is not the only channel leading to these effects. Buyers could have been unaware that entire vintages were affected, but were able to determine through inspection that some equipment pieces were of inferior quality.

Since the average resale price of US equipment sold is approximately $\$ 80,000$, the estimated dispute effect implies that equipment buyers paid approximately $\$ 4,000$ fewer dollars for equipment produced in a facility undergoing a labor dispute. The model of the durable goods resale market suggests that the change in resale price for dispute-affected equipment relative to the comparison group can be interpreted as the change in the discounted stream of service flows for the marginal consumer. Therefore, a simple lower bound for the lost rents resulting from the dispute is $\$ 4,000$ times the number of equipment affected by the dispute (approximately 100,000 pieces), resulting in a loss of service flow of more than $\$ 400$ million. 
An interesting question to consider is how the cost Caterpillar potentially incurred by producing lower quality equipment compares to the savings Caterpillar obtained by demanding concessions from the UAW. This comparison is possible since the counterfactual labor contract is known - the contract Deere signed with the UAW in 1991 and which Caterpillar would have signed if they continued with pattern bargaining. Assuming that dispute-affected equipment experienced $\$ 400$ million in lost service flows, as estimated, the dispute would have led to at most $\$ 400$ million reduction in Caterpillar revenue arising from reduced product quality (and exactly $\$ 400$ million if increased physical depreciation of older equipment was fully shifted to new prices). According to industry analysts at the time of the strike, the contract signed with Deere would have increased labor costs at Caterpillar by about $\$ 250$ million over the life of the three year contract [Kelly (1992)]. Over the entire 6-plus years of the dispute the difference in wage bills between Caterpillar and Deere was on the order of $\$ 500$ million. ${ }^{45}$ If Caterpillar did not revert back to the Deere settlement after six years, then the net present value of breaking from pattern is on the order of $\$ 1.4$ billon, outweighing even the maximum costs Caterpillar could have incurred due to the quality reductions alone.

Of course, the dispute led to additional costs in addition to lower product quality. These include lost sales due to reduced production, as well as lost sales due to consumers switching brands, perhaps because of lower quality equipment. While I am unable to estimate the potentially large loss in Caterpillar market share relative to the counterfactual situation of no dispute, it is possible to bound the direct costs of the strike due to lost sales. The two strikes lasted approximately two year. I estimate that the strikes led to approximately a $12 \%$ reduction in output in affected plants. Assuming that none of this reduced production was offset by increased foreign production, or future sales, this reduction led to approximately 3,250 fewer pieces of new equipment produced. In this scenario, production cuts would have led to $\$ 970$ million in lost revenue, given an average list price of new equipment of $\$ 300,000$. Even if there were zero costs associated with producing equipment (clearly false), this reduction in profits would not have been enough to close the gap between the benefits the firm obtained from breaking with the union to the direct

\footnotetext{
45 In 1995 Deere signed a new contract with the UAW that extended the base wages set in the previous contract [Daily Labor Report (1995)].
} 
and indirect costs of the dispute. ${ }^{46}$ This being said, it is important to reemphasize that there were other costs in the strike which are not incorporated into this calculation.

The precise mechanism which led workers to produce inferior equipment has not been fully addressed. For both the appraisal and resale price outcomes, resale market participants discounted US equipment produced through virtually the entire period of the dispute, indicating that quality differences in US-dispute equipment cannot be solely attributable to the use of salaried or replacement workers. ${ }^{47}$ The timing of the quality effects is consistent with findings in Krueger and Mas (2004) who observe a similar pattern in the production of defective tires at Bridgestone/Firestone during a period of labor unrest. Katz, Kochan and Gobeille (1983) find that the industrial relations measure with the strongest correlation to the production of General Motors automobiles that did not pass inspection is the negotiation time for a new contract, also consistent with the evidence cited in this paper as the dispute between Caterpillar and the UAW was characterized by difficult negotiations.

A striking feature of this dispute is its substantial length and the fact that the union ultimately agreed to a contract that was virtually identical to the one initially proposed by the employer. Why did the union held out for so long in bargaining, even though the potential direct cost of a strike to Caterpillar was diminished by the company's insistence that striking workers would be permanently replaced? When viewed through the lens of a war-of-attrition model of bargaining, the reduction in product quality documented here provides one way to make sense of this aspect of the dispute. ${ }^{48}$

In the war-of-attrition model of bargaining, two parties with linear costs of delay-that are unknown to the opposing party-fight over a fixed prize in a winner-take-all contest. The game ends when one party capitulates. Delay occurs because parties do not know the opponents cost of delay with certainty, so bargaining continues until one party is sufficiently convinced that the opposing party has lower cost of continuation. In equilibrium, the party with the higher cost of continuation capitulates form,

\footnotetext{
${ }^{46}$ This is not to say that the union did not benefit from reducing effort. Lower product quality represents an elevated cost of delay for the employer and, in theory, may have led to the firm to settle at a wage that was higher than if there were no product quality reduction.

${ }^{47}$ One application of this finding is to legislation that seeks to amend the National Labor Relations Act to prohibit employers from hiring permanent replacement workers during strike. For example, in 1993 the US House of Representatives voted 239-190 to amend the National Labor Relations Act (the bill never reached the Senate due to a threatened filibuster.) The findings here suggest that whether replacement workers are building defective products due to inexperience should not be a central focus of this debate.
} 
which occurs when the marginal cost of delay is equal to the size of the award times the probability that the opponent will capitulate conditional on having waited up to that point. ${ }^{49}$

That the dispute was of substantial length, and that there was no compromise, is suggestive of an outcome from this kind of war-of-attrition bargaining. Of course, this model is well-suited to explain the duration and outcome of strikes, when the firm clearly faces a cost of delay. However, the dispute in this study is characterized by long periods of bargaining without strikes, where it is not obvious that the firm had anything to lose by not signing a contract. Reduced product quality, as documented in this paper, could play a role in explaining why the union would not settle with the employer immediately. By reducing effort, the union imposes a cost to the employer that could be significant in magnitude, but also a cost that may be difficult for the union to estimate precisely. The existence of such a cost, in the presence of asymmetric information, could have led the union to hold out in bargaining in the hope that the marginal cost of delaying an agreement arising from lower product quality was higher than the marginal cost of delay for the union. ${ }^{50}$ In this case, the union eventually gave in when it became sufficiently clear that the firm's marginal cost of delay due to reduced product quality was not high enough. ${ }^{51,52}$

\footnotetext{
${ }^{48}$ See Kennan and Wilson (1989) and Card and Olson (1995) for a discussion of the war-of-attrition model in the context of strikes, and associated empirical tests.

${ }^{49}$ Concretely, using the notation of Kennan and Wilson (1989), each party has a marginal cost of continuation $c_{i}$ which is unknown to the opposing party. The size of the award is $v$. A party holds out until the marginal cost of delay is equal to the marginal benefit, which is equal to the size of the award times the probability that the other player will quit in that period. That is, a party quits when $\mathrm{c}(\mathrm{i})=\mathrm{v}^{*} \mathrm{q}_{\mathrm{t}}$, where $\mathrm{q}_{\mathrm{t}}$ is the probability of the opponent exiting at time $t$ conditional on reaching $t$. In equilibrium, a player quits when the maximum profitable duration before concession $-\mathrm{v} / c_{l}-$ is equal to $1 / \mathrm{q}_{\mathrm{t}}$. The party with the higher marginal cost of continuation exits first.

${ }_{51}^{50}$ Another cost of delay to the firm is the possibility of consumer boycotts.

${ }^{51}$ There are of course other models that can be used to explain some of the features of the dispute. For example, in Hart's (1989) model of bargaining, strikes of substantial length are shown to occur when there are delays between rounds in bargaining, asymmetric information of the firm's rents, and a non-linear cost of delay for the firm. Under these conditions, the union has option value from delaying settlements. Reduced product quality could have created a non-linear component in the cost of delay necessary for a lengthy dispute. In MacLeod (2003), the threat of conflict ensures that management will reward employees as a function of management's true assessment of performance. In this context, that the threat of reduced performance was exercised suggests that management's assessment of profitability diverged from the workers assessment, perhaps because Caterpillar was demanding concessions from its workers while its earnings were on the rise.

${ }^{52}$ Knowing that quality was declining management could have changed monitoring intensity. However, this is an environment where eliciting additional effort would be difficult. Because production is complex, management would likely have had to employ substantially more supervisors in order to effectively monitor the workers. Here is a case where it may have been more efficient for the company to rely on stable industrial relations than on additional monitoring to elicit high-levels of effort.
} 


\section{Conclusion}

The evidence assembled in this paper provides consistent support for the conclusion that labor unrest impacted the quality of production. The temporal patterns of resale prices, appraisal reports, resale rates and list prices for pieces of US-made and dispute-era equipment support the theoretical model's predictions for a reduction in product quality in a durable goods market. Resale market participants discounted equipment produced in the US during the dispute by about 5\%. Additionally, this equipment was much less likely to be classified in the top condition categories, experienced resale rates that are about $30 \%$ higher than other comparable equipment, and was given a sticker price that was at least $1.5 \%$ lower.

It is always possible that there were unobserved factors that resulted in worse physical state, lower resale prices, higher resale rates and lower resale prices for equipment produced in US plants during the span of time the UAW workers did not have a contract. However, the research design and the statistical methods employed in this paper rule out many other explanations for the observed patterns, including supply shifts, changes in distributional patterns, differences in the composition of equipment produced at US and foreign plants, and changes in the composition of the workforce, as would be expected from the opening of several non-union plants during the dispute.

The reduction in product quality on lost service flows was large, totaling approximately half a billion dollars. There is evidence that list prices were affected, suggesting that at least some of these lost service flows affected Caterpillar's profitability. As indicated in the discussion, it unlikely that these losses dominated the rents Caterpillar extracted in breaking with the union. The finding that there was a reduction on the effort margin during the dispute potentially helps explain why it took so long for a new contract to be signed between the two disputing parties. The reduction in product quality may have created a cost of delay for the company that was large enough for the union to hold out in bargaining, but ultimately not large enough for the union to emerge victorious in a war-of-attrition. 


\section{References}

Ahn, Hyuntaik and Powell, James L. "Semiparametric Estimation of Censored Selection Models With a Nonparametric Selection Mechanism," Journal of Econometrics 58 (July 1993): 3-29.

Baily, Neil, Charles Hulten, and David Campbell, "Productivity Dynamics in Manufacturing Plants." Brookings Papers on Economic Activity: Microeconomics, 1992: pp. 187-268.

Bartel, Ann; Freeman, Richard; Ichniowski, Casey; and Kleiner, Morris. "Can a Work Organization Have an Attitude Problem? The Impact of Workplaces on Employee Attitudes and Economic Outcomes," NBER Working Paper No. w9987, September 2003.

Boiarsky, Carolyn. “Caterpillar Continues to Prosper.” Illinois Issues, June 1994.

Bollinger, Christopher and Chandra, Amitabh. "Iatrogenic Specification Error: A Cautionary Tale of Cleaning Data," University of Kentucky mimeo, July 2003.

Cameron, A. Colin and Trivedi, Pravin. Regression Analysis of Count Data, Cambridge, UK: Cambridge University Press, Econometric Society Monograph, 1998.

Card, David and Olson, Craig. "Bargaining Power, Strike Duration, and Wage Outcomes: An Analysis of Strikes in the 1880's," Journal of Labor Economics, January 1995, pp. 32-61.

Card, David and Payne, Abigail A. "School Finance Reform, the Distribution of School Spending, and the Distribution of SAT Scores," Journal of Public Economics, January 2002, pp. 49-82.

Cimini, Michael. "Caterpillar's Prolonged Dispute Ends," Compensation and Working Conditions, US Department of Labor, Bureau of Labor Statistics, Fall 1998: 4-11.

Cohen, Issac. "The Caterpillar Labor Dispute and the UAW, 1991-1998." Labor Studies Journal, Winter 2002. pp. 77-99.

Daily Labor Report, No. 65, April 3, 1992, p. A-4.

Daily Labor Report, No. 44, March 7, 1995, p. A-12.

The Economist, "Union Bull," January 9, 1993, p. 61.

Eckert, Toby. “Cat v UAW: Pattern Bargaining at Issue,” Illinois Issues, March 1992.

Engineering News-Record, "CAT, UAW still at odds," August 31, 1992, p. 14.

Fernald, John, and Shanthi Ramnath. "The Acceleration of U.S. Total Factor Productivity after 1995: The Role of Information Technology," Economic Perspectives. Q1 2004: pp. 52-67.

Franklin, Stephen. Three Strikes, New York: The Guilford Press, 2001.

Freeman, Richard and Medoff, James. What Do Unions Do? New York: Basic Books, 1984.

Genesove, David, "Adverse Selection in the Wholesale Used Car Market." Journal of Political Economy, August 1993, pp. 644-665.

Hart, Oliver. "Bargaining and Strikes,” Quarterly Journal of Economics, February 1989, pp. 25-43. 
Harter, James, Frank Schmidt, and Theodore Hayes, "Business-Unit-Level Relationship Between Employee Satisfaction, Employee Engagement, and Business Outcomes: A Meta-Analysis," Journal of Applied Psychology, 87 2002: pp. 268-79

Hendel, Igal and Lizzeri, Alessandro. "Adverse Selection in Durable Goods Markets," American Economic Review, December 1999, pp. 1097-1115.

Hendricks, Wallace E. and Kahn, Lawrence M. "Efficiency Wages, Monopoly Unions and Efficient Bargaining," The Economic Journal, September 1991, pp. 1149-1162.

Katz, Harry C.; Kochan, Thomas A.; and Gobeille, Kenneth R. "Industrial Relations Performance, Economic Performance, and QWL Programs: An Interplant Analysis," Industrial and Labor Relations Review, October 1983, pp. 3-17.

Kelly, Kevin. "This Brawl Could Cost CAT a Couple of its lives.” Business Week, March 23, 1992, p. 82.

Kennan, John and Wilson, Robert. "Strategic Bargaining Models and Interpretation of Strike Data." Journal of Applied Econometrics, December 1989, pp. S87-S101.

Kleiner, Morris M.; Leonard, Jonathan S.; and Pilarski, Adam M. "How Industrial Relations Affect Plant Performance: The Case of Commercial Aircraft Manufacturing," Industrial and Labor Relations Review, January 2002, pp. 195-218.

Krueger, Alan B. and Mas, Alexandre. "Strikes, Scabs and Tread Separations: Labor Strife and the Production of Defective Bridgestone/Firestone Tires," Journal of Political Economy, April 2004, pp. 253-289.

MacLeod, Bentley. "Optimal Contracting with Subjective Evaluation," American Economic Review, March 2003, pp. 216-239.

Malcomson, James. "Individual Employment Contracts," In Orley Ashenfelter and David Card (eds.), Handbook of Labor Economics, vol. 3B, chapter 35, 1999, pp. 2291-2372.

Mas, Alexandre. "Pay, Reference Points, and Police Performance," Quarterly Journal of Economics, August 2006, pp. 783-821.

Mining Week, "Caterpillar Rancour,” October 9, 1992, p. 251.

Shapiro, Carl and Stiglitz, Joseph P. "Equilibrium Unemployment as a Worker Discipline Device," American Economic Review, June 1984, pp. 433-444.

Syverson, Chad. "Product Substitutability and Productivity Dispersion," Review of Economics and Statistics, 2004.

Porter, Robert and Sattler, Peter. "Patterns of Trade in the Market for Used Durables: Theory and Evidence," NBER Working Paper, May 1999.

Thompson, Peter. "How Much Did the Liberty Shipbuilders Learn? New Evidence for an Old Case Study," Journal of Political Economy, February 2001, pp. 103-137.

Wooldridge, Jeffrey. "Distribution-Free Estimation of Some Nonlinear Panel Data Models," Journal of Econometrics, May 1999, pp. 77-97. 


\section{Appendix A: Descriptions of the algorithm bounding production years and the calculation of assembly-line level production.}

The serial number guide assigns each serial number the year the equipment with that number was

shipped. Serial numbers are stamped on equipment sequentially as they are produced on the assembly line. As such, if the wheel loader with serial number XXX950 was shipped in 1992, XXX951 was shipped in 1993, and XXX952 was shipped in 1992, it must be that XXX951 was produced no later than 1992 even though it was shipped in 1993. Using this logic, I developed a simple algorithm that calculates the last year equipment could have been produced. The algorithm allocates each piece of equipment to an upper bound of the year of production by assigning it the earliest year of shipment of all equipment with a higher, or equal, serial number. Moving sequentially down from the last serial number in a series, cutpoints are identified as the first instance of a new year. While this algorithm generates some error in the measurement of yearly production, the measurement error is unambiguously less severe than using shipment year as a proxy for production year. Still, if inventory is characterized by buffer-stock behavior, measured production continues to underestimate true production during periods of inventory build-up and overestimates it during run-offs.

As a corollary to this procedure assembly line level yearly production is estimated as the difference between the last and first serial numbers between cut-points plus 1 . Some additional care is taken to account for gaps in the sequence of serial numbers. The number of years equipment is held in inventory by Caterpillar is estimated as the difference in shipment year and the estimated production year. Because year of production is estimated, there are 496 observations that have negative inventories assigned to them. Because discarding these observations could result in additional bias [see e.g. Bollinger and Chandra (2003)], they are kept in the sample. 


\section{Appendix B: Description of the Monetized Condition Index.}

The monetized condition index is constructed by estimating the equation:

$$
\begin{aligned}
& \ln p_{i c}=\alpha+\beta^{\prime} \mathrm{X}+\gamma_{c}+\eta_{\mathrm{E}} \text { EXCELLENT }_{i}+\eta_{\mathrm{VG}} \text { VERY GOOD }_{i}+\eta_{\mathrm{G}} \mathrm{GOOD}_{i} \\
& \eta_{\mathrm{F}} \mathrm{FAIR}_{i}+\eta_{\mathrm{U}} \mathrm{UNKNOWN}_{i}+\eta_{\mathrm{P}} \mathrm{POOR}_{i}+\varepsilon_{i c}
\end{aligned}
$$

where the vector of covariates $\mathrm{X}$ contains years in inventory dummies, seven region of auction dummies, month of auction dummies, and age of the production line at the time the equipment was produced.

Estimated coefficients $\hat{\eta}_{\mathrm{E}}, \hat{\eta}_{\mathrm{VG}}, \hat{\eta}_{\mathrm{G}}, \hat{\eta}_{\mathrm{U}}, \hat{\eta}_{\mathrm{F}}$, and $\hat{\eta}_{\mathrm{P}}$ were multiplied by 100 are assigned as the values for the monetized condition index. 
Figure 1. Complaints to OSHA from Workers in American Caterpillar and Deere Unionized Plants

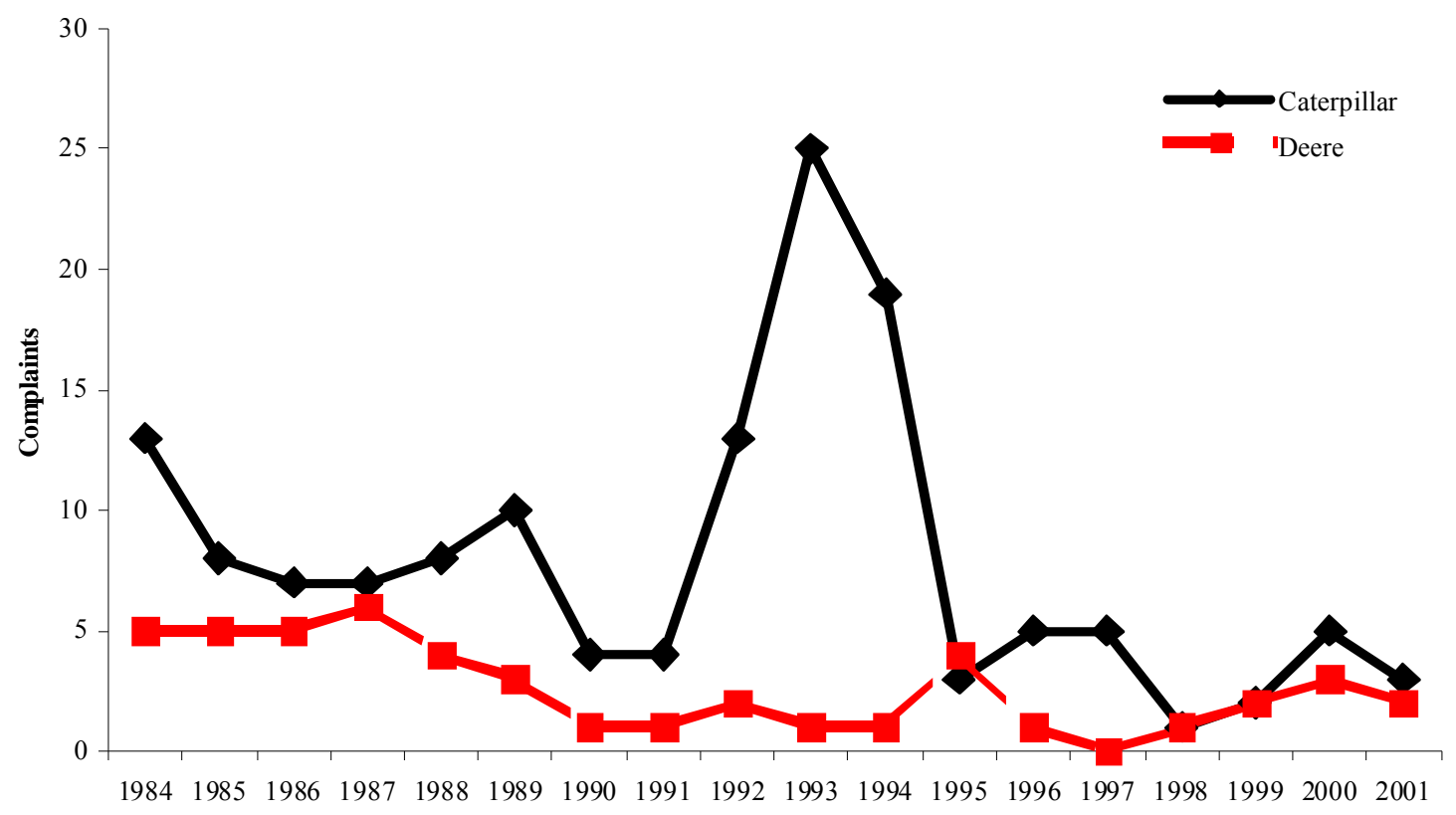

Figure 2. Proportion of Caterpillar Complaints that resulted in DOL Violations

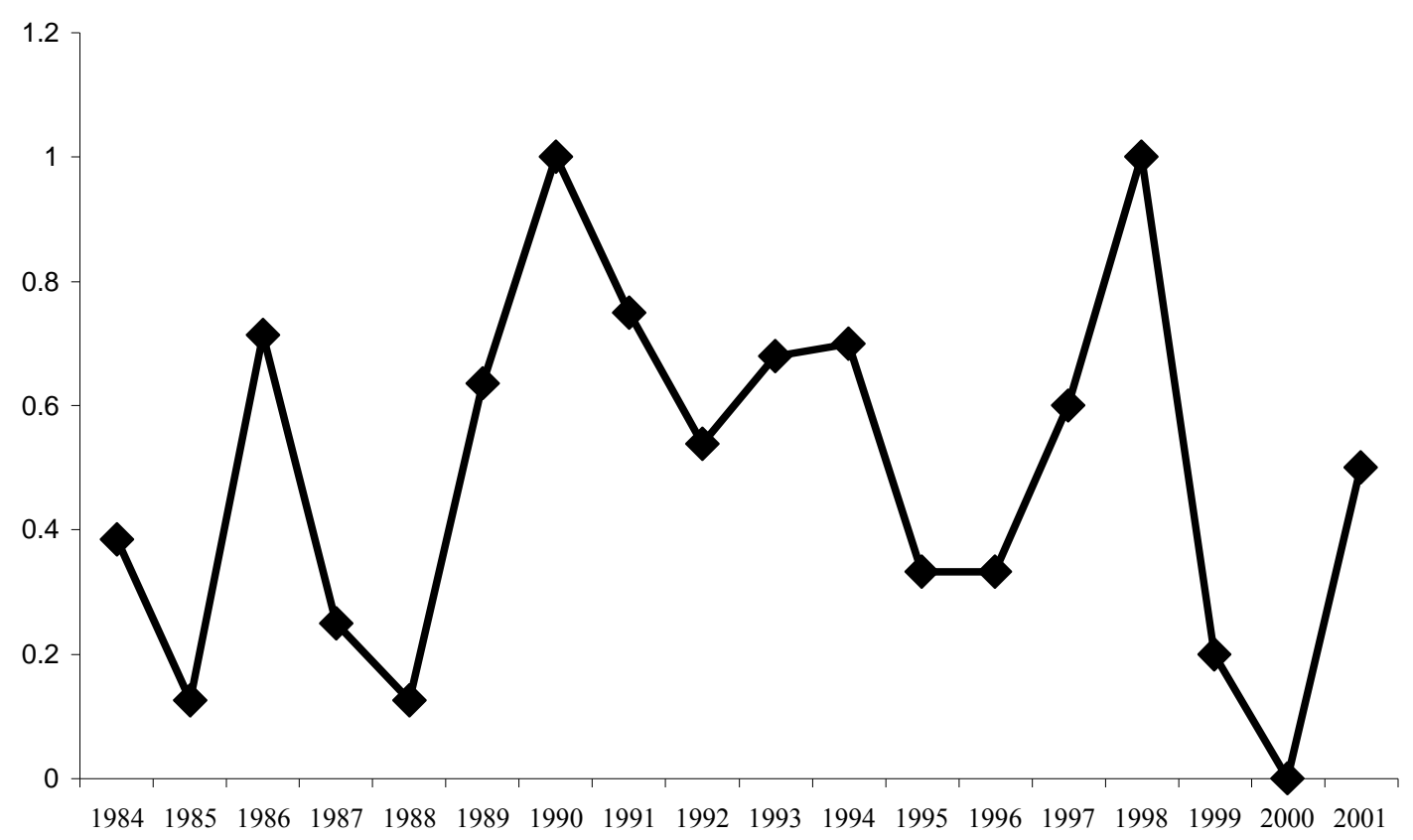




\section{Figure 3. Regression-Adjusted US-Foreign Monetized Condition Index}

\section{Differential by Year of Production}

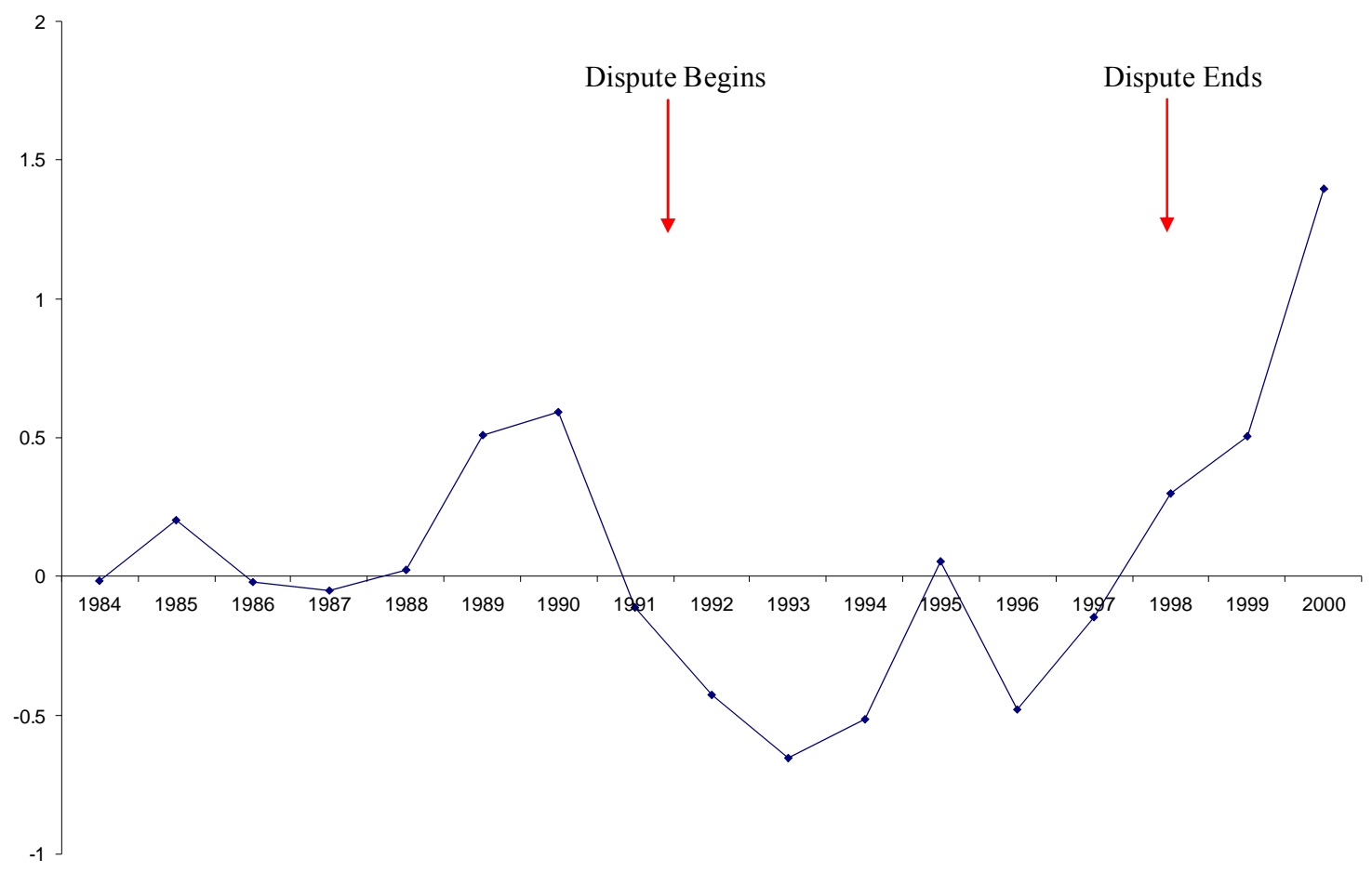

Note: This figure plots $\hat{\delta}_{1984}-\hat{\delta}_{2000}$, which are obtained from estimating equation (14), using the monetary condition index as the dependent variable. The sample corresponds to pieces of equipment from model years 1984 through 2000 for transactions occurring between January 1994 and September 2002. Only models that have both US and foreign production are included in the sample. 
Figure 4. Regression-Adjusted US-Foreign Log Resale Price Differential by Year of Production

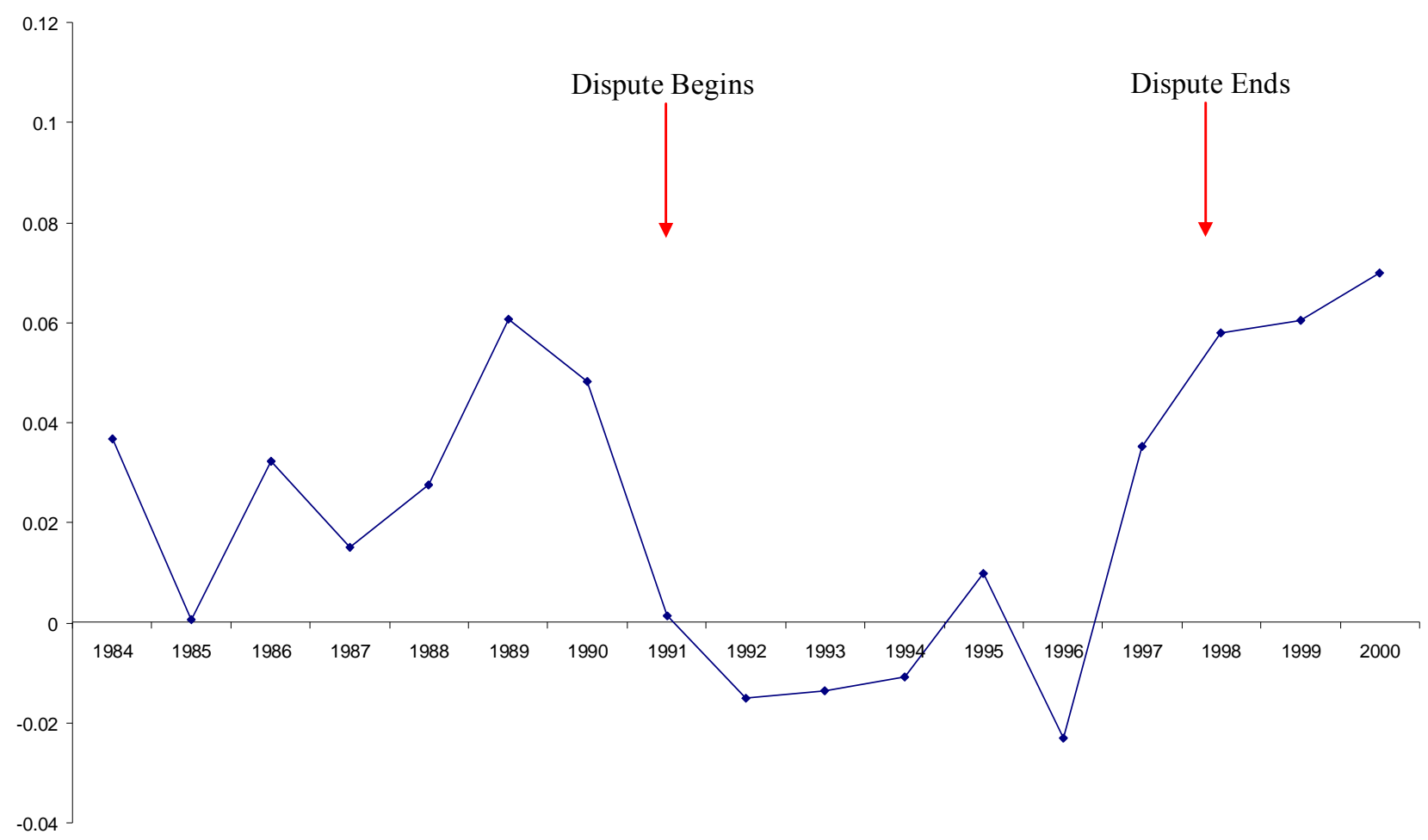

Note: This figure plots $\hat{\delta}_{1984}-\hat{\delta}_{2000}$, which are obtained from estimating equation (14). The sample corresponds to pieces of equipment from model years 1984 through 2000 for transactions occurring between January 1994 and September 2002. Only models that have both US and foreign production are included in the sample. 
Figure 5. US-foreign List Price Differential by Production Year

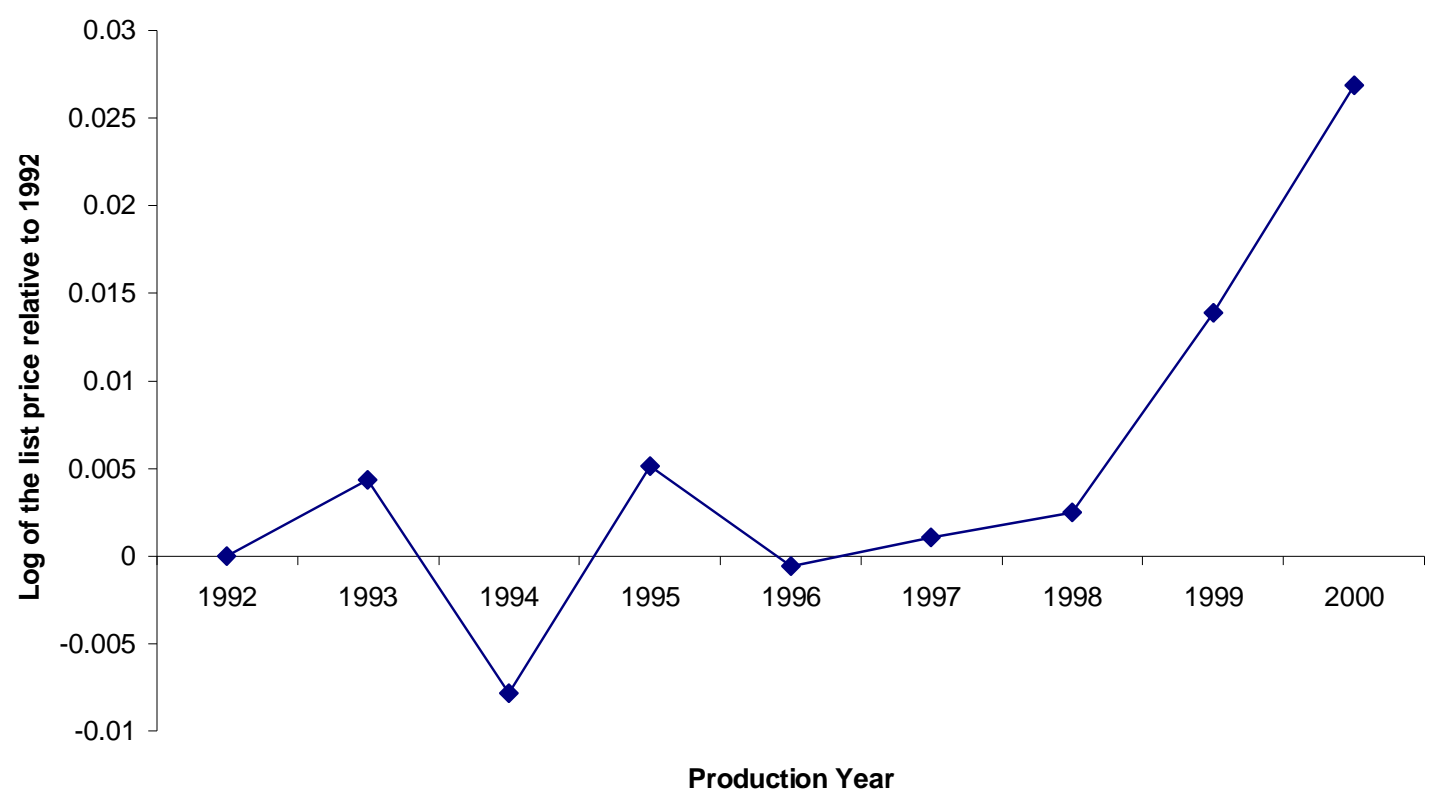

Note: See text for details on construction of the figure. 
Table 1: Summary statistics

\begin{tabular}{|c|c|c|c|c|c|c|c|}
\hline$\underline{\text { Explanatory Variables }}$ & $\begin{array}{l}\text { US: } \\
\text { Pre-dispute }\end{array}$ & $\begin{array}{l}\text { US: } \\
\text { Dispute }\end{array}$ & $\begin{array}{l}\text { US: } \\
\text { Post-dispute }\end{array}$ & $\begin{array}{l}\text { Foreign: } \\
\text { Pre-dispute }\end{array}$ & $\begin{array}{l}\text { Foreign: } \\
\text { Dispute }\end{array}$ & $\begin{array}{l}\text { Foreign: } \\
\text { Post-dispute }\end{array}$ & Full-Sample \\
\hline Transaction price & $\begin{array}{l}79,262 \\
{[53,556]}\end{array}$ & $\begin{array}{l}92,140 \\
{[68,220]}\end{array}$ & $\begin{array}{l}88,603 \\
{[65,805]}\end{array}$ & $\begin{array}{l}34,713 \\
{[23,844]}\end{array}$ & $\begin{array}{l}51,425 \\
{[35,042]}\end{array}$ & $\begin{array}{l}62,180 \\
{[40,363]}\end{array}$ & $\begin{array}{l}61,983 \\
{[50,871]}\end{array}$ \\
\hline Dispute $($ Yes $=1)$ & 0 & 1 & 0 & 0 & 1 & 0 & 0.52 \\
\hline Production year & $\begin{array}{l}1987.3 \\
{[1.93]}\end{array}$ & $\begin{array}{l}1994.2 \\
{[1.86]}\end{array}$ & $\begin{array}{l}1998.4 \\
{[0.58]}\end{array}$ & $\begin{array}{l}1987.8 \\
{[1.73]}\end{array}$ & $\begin{array}{l}1994.0 \\
{[1.85]}\end{array}$ & $\begin{array}{l}1998.5 \\
{[0.68]}\end{array}$ & $\begin{array}{l}1991.7 \\
{[4.03]}\end{array}$ \\
\hline Auction year & $\begin{array}{l}1997.9 \\
{[2.59]}\end{array}$ & $\begin{array}{l}1999.2 \\
{[2.0]}\end{array}$ & $\begin{array}{l}2001.1 \\
{[0.81]}\end{array}$ & $\begin{array}{l}1997.7 \\
{[2.49]}\end{array}$ & $\begin{array}{l}1999.1 \\
{[2.03]}\end{array}$ & $\begin{array}{l}2001.2 \\
{[0.79]}\end{array}$ & $\begin{array}{l}1998.7 \\
{[2.39]}\end{array}$ \\
\hline $\begin{array}{l}\text { Produced in the US } \\
(\text { Yes }=1)\end{array}$ & 1 & 1 & 1 & 0 & 0 & 0 & 0.40 \\
\hline $\begin{array}{l}\text { Produced in US during } \\
\text { the dispute }(\text { Yes }=1)\end{array}$ & 0 & 1 & 0 & 0 & 1 & 0 & 0.19 \\
\hline $\begin{array}{l}\text { Sold at auction } \\
\text { in the US }(\text { Yes }=1)\end{array}$ & 0.81 & 0.84 & 0.89 & 0.75 & 0.77 & 0.79 & 0.79 \\
\hline Age & $\begin{array}{l}10.5 \\
{[3.3]}\end{array}$ & $\begin{array}{l}5.0 \\
{[2.1]}\end{array}$ & $\begin{array}{l}2.7 \\
{[0.9]}\end{array}$ & $\begin{array}{l}9.9 \\
{[3.0]}\end{array}$ & $\begin{array}{l}5.1 \\
{[2.1]}\end{array}$ & $\begin{array}{l}2.7 \\
{[0.9]}\end{array}$ & $\begin{array}{l}7.0 \\
{[3.7]}\end{array}$ \\
\hline $\begin{array}{l}\text { Age of the Production } \\
\text { line }\end{array}$ & $\begin{array}{l}2.1 \\
{[1.6]}\end{array}$ & $\begin{array}{l}2.7 \\
{[2.7]}\end{array}$ & $\begin{array}{l}2.8 \\
{[1.1]}\end{array}$ & $\begin{array}{l}1.7 \\
{[1.4]}\end{array}$ & $\begin{array}{l}2.2 \\
{[2.1]}\end{array}$ & $\begin{array}{l}2.3 \\
{[1.2]}\end{array}$ & $\begin{array}{l}2.2 \\
{[2.0]}\end{array}$ \\
\hline $\begin{array}{l}\text { Years in } \\
\text { Inventory }\end{array}$ & $\begin{array}{l}0.11 \\
{[0.47]}\end{array}$ & $\begin{array}{l}0.08 \\
{[0.47]}\end{array}$ & $\begin{array}{l}0.02 \\
{[0.16]}\end{array}$ & $\begin{array}{l}0.14 \\
{[0.62]}\end{array}$ & $\begin{array}{l}0.10 \\
{[0.43]}\end{array}$ & $\begin{array}{l}0.05 \\
{[0.29]}\end{array}$ & $\begin{array}{l}0.10 \\
{[0.49]}\end{array}$ \\
\hline Condition index & $\begin{array}{l}27.1 \\
{[3.4]}\end{array}$ & $\begin{array}{l}28.2 \\
{[3.4]}\end{array}$ & $\begin{array}{l}29.0 \\
{[2.9]}\end{array}$ & $\begin{array}{l}26.7 \\
{[3.7]}\end{array}$ & $\begin{array}{l}27.8 \\
{[3.1]}\end{array}$ & $\begin{array}{l}28.7 \\
{[3.1]}\end{array}$ & $\begin{array}{l}27.6 \\
{[3.4]}\end{array}$ \\
\hline \multicolumn{8}{|l|}{$\begin{array}{l}\text { Condition } \\
\text { reported as: }\end{array}$} \\
\hline Excellent (\%) & 0.9 & 2.5 & 5.2 & 0.30 & 1.7 & 4.8 & 1.6 \\
\hline Very good & 8.5 & 18.7 & 21.5 & 7.6 & 14.6 & 18.0 & 13.0 \\
\hline Good & 61.0 & 57.0 & 57.4 & 50.9 & 53.3 & 54.8 & 55.1 \\
\hline Fair & 10.8 & 6.6 & 1.7 & 13.7 & 6.3 & 1.7 & 8.6 \\
\hline Poor & 0.3 & 0.2 & 0.0 & 0.6 & 0.2 & 0.2 & 0.3 \\
\hline Unknown & 18.5 & 18.7 & 21.5 & 27.0 & 24.0 & 20.5 & 21.5 \\
\hline
\end{tabular}


Table 2: Effect of the Labor Dispute on Appraisals;

Dependent Variable: Monetized Condition Index

(1) (2)

(3)

(4)

(5)

Produced Produced

Explanatory Variables

1992-2000 1984-1997

\begin{tabular}{|c|c|c|c|c|c|c|}
\hline US $\times$ Dispute & $\begin{array}{l}-0.21 \\
(0.09)\end{array}$ & $\begin{array}{l}-0.59 \\
(0.11)\end{array}$ & $\begin{array}{l}-0.54 \\
(0.10)\end{array}$ & $\begin{array}{l}-0.66 \\
(0.11)\end{array}$ & $\begin{array}{l}-0.76 \\
(0.12)\end{array}$ & $\begin{array}{l}-0.53 \\
(0.12)\end{array}$ \\
\hline Produced in the US & $\begin{array}{l}0.16 \\
(0.07)\end{array}$ & $\begin{array}{l}0.29 \\
(0.08)\end{array}$ & $\begin{array}{l}0.23 \\
(0.09)\end{array}$ & $\begin{array}{l}0.05 \\
(0.13)\end{array}$ & $\begin{array}{l}0.35 \\
(0.11)\end{array}$ & $\begin{array}{l}0.22 \\
(0.11)\end{array}$ \\
\hline $\begin{array}{l}\text { Produced during the } \\
\text { Dispute }\end{array}$ & $\begin{array}{l}-0.14 \\
(0.08)\end{array}$ & & & & & \\
\hline Age & $\begin{array}{l}-0.51 \\
(0.03)\end{array}$ & & & & & \\
\hline $\operatorname{Age}^{2}($ estimate $\times 100)$ & $\begin{array}{l}1.53 \\
(0.18)\end{array}$ & & & & & \\
\hline Production-line age & & & $\begin{array}{l}0.07 \\
(0.03)\end{array}$ & $\begin{array}{l}0.07 \\
(0.03)\end{array}$ & $\begin{array}{l}0.06 \\
(0.03)\end{array}$ & $\begin{array}{l}0.07 \\
(0.03)\end{array}$ \\
\hline Years in inventory & & & $\begin{array}{l}0.13 \\
(0.07)\end{array}$ & $\begin{array}{l}0.13 \\
(0.07)\end{array}$ & $\begin{array}{l}0.31 \\
(0.09)\end{array}$ & $\begin{array}{l}0.13 \\
(0.07)\end{array}$ \\
\hline $\ln \left(\pi_{a t \tau}\right)^{\wedge}$ & & & $\begin{array}{l}0.02 \\
(0.05)\end{array}$ & $\begin{array}{l}0.04 \\
(0.06)\end{array}$ & $\begin{array}{l}0.11 \\
(0.07)\end{array}$ & $\begin{array}{l}-0.03 \\
(0.06)\end{array}$ \\
\hline Model effects $\{353\}$ & Yes & & & & & \\
\hline Auction year dummies $\{9\}$ & Yes & & & & & \\
\hline Cohort effects $\{2,366\}$ & & Yes & Yes & Yes & Yes & Yes \\
\hline US $\times$ production year trend & & & & Yes & & \\
\hline Region and season controls & & & Yes & Yes & Yes & Yes \\
\hline Mean of the & 27.6 & 27.7 & 27.7 & 27.7 & 28.2 & 27.6 \\
\hline Dependent variable & {$[3.4]$} & {$[3.5]$} & {$[3.5]$} & {$[3.5]$} & {$[3.3]$} & {$[3.5]$} \\
\hline Observations & 42,841 & 17,153 & 17,153 & 17,153 & 9,664 & 15,847 \\
\hline$R^{2}$ & 0.17 & 0.32 & 0.34 & 0.34 & 0.34 & 0.34 \\
\hline
\end{tabular}

Notes: Standard errors clustered on production-line are in parentheses. Standard deviations are in brackets. Number of categories in a group is in braces. The dependent variable is the monetized condition index. The full sample corresponds to pieces of equipment from model years 1984 through 2000 for transactions occurring between January 1994 and September 2002. Models with cohort-effects use the sub-sample of models that have both US and foreign production. The dispute period is defined as the years spanning 1991 through 1997. When pieces of equipment appear multiple times in the sample, only the first transaction is used. All models include a constant. Region and season controls consist of seven region dummies andmonth of auction dummies. See text for further details on the controls.

$\wedge$ Selectivity adjustment 
Table 3: Effect of the Labor Dispute on Appraisals; Ordered probit model

\begin{tabular}{|c|c|c|c|c|c|c|}
\hline & $\begin{array}{l}\text { Log odds } \\
\text { estimate }\end{array}$ & & & ginal Ef & $100)$ & \\
\hline & (1) & $\begin{array}{l}(2) \\
\text { Poor }\end{array}$ & $\begin{array}{l}(3) \\
\text { Fair }\end{array}$ & $\begin{array}{l}\text { (4) } \\
\text { Good } \\
\end{array}$ & $\begin{array}{l}(5) \\
\text { Very Good }\end{array}$ & $\begin{array}{l}(6) \\
\text { Excellent }\end{array}$ \\
\hline US $\times$ Dispute & $\begin{array}{l}-0.12 \\
(0.05)\end{array}$ & $\begin{array}{l}0.033 \\
(0.016)\end{array}$ & $\begin{array}{l}1.62 \\
(0.68)\end{array}$ & $\begin{array}{l}0.83 \\
(0.25)\end{array}$ & $\begin{array}{l}-2.29 \\
(0.087)\end{array}$ & $\begin{array}{l}-0.19 \\
(0.07)\end{array}$ \\
\hline Relative frequency (\%) & & 0.07 & 6.9 & 79.4 & 13.1 & 0.62 \\
\hline
\end{tabular}


Table 4: Effect of the Labor Dispute on the US-Foreign Resale Price Differential;

Dependent Variable: Log Resale Transaction Price

(1) (2)

$(3)$
(4)

(5)

Produced

$1992-2000$
(6)

Produced
1984-1997

(7)

(1)

Explanatory Variables

\begin{tabular}{|c|c|c|c|c|c|c|c|}
\hline US $\times$ Dispute & $\begin{array}{l}0.011 \\
(0.013)\end{array}$ & $\begin{array}{l}-0.044 \\
(0.010)\end{array}$ & $\begin{array}{l}-0.040 \\
(0.011)\end{array}$ & $\begin{array}{l}-0.054 \\
(0.018)\end{array}$ & $\begin{array}{l}-0.061 \\
(0.030)\end{array}$ & $\begin{array}{l}-0.035 \\
(0.013)\end{array}$ & $\begin{array}{l}-0.035 \\
(0.011)\end{array}$ \\
\hline Produced in the US & $\begin{array}{l}0.025 \\
(0.011)\end{array}$ & $\begin{array}{l}0.059 \\
(0.011)\end{array}$ & $\begin{array}{l}0.039 \\
(0.013)\end{array}$ & $\begin{array}{l}0.020 \\
(0.017)\end{array}$ & $\begin{array}{l}0.058 \\
(0.034)\end{array}$ & $\begin{array}{l}0.035 \\
(0.012)\end{array}$ & $\begin{array}{l}0.037 \\
(0.013)\end{array}$ \\
\hline $\begin{array}{l}\text { Produced During the } \\
\text { Dispute }\end{array}$ & $\begin{array}{l}-0.009 \\
(0.010)\end{array}$ & & & & & & \\
\hline Age & $\begin{array}{l}-0.120 \\
(0.006)\end{array}$ & & & & & & \\
\hline $\operatorname{Age}^{2}($ estimate $\times 100)$ & $\begin{array}{l}0.287 \\
(0.030)\end{array}$ & & & & & & \\
\hline Production-line age & & & $\begin{array}{l}-0.001 \\
(0.005)\end{array}$ & $\begin{array}{l}-0.001 \\
(0.005)\end{array}$ & $\begin{array}{l}0.001 \\
(0.004)\end{array}$ & $\begin{array}{l}-0.000 \\
(0.005)\end{array}$ & $\begin{array}{l}-0.002 \\
(0.005)\end{array}$ \\
\hline Years in inventory & & & $\begin{array}{l}0.036 \\
(0.006)\end{array}$ & $\begin{array}{l}0.036 \\
(0.006)\end{array}$ & $\begin{array}{l}0.047 \\
(0.008)\end{array}$ & $\begin{array}{l}0.035 \\
(0.006)\end{array}$ & $\begin{array}{l}0.035 \\
(0.005)\end{array}$ \\
\hline $\ln \left(\pi_{a t \tau}\right)$ & & & $\begin{array}{l}-0.014 \\
(0.006)\end{array}$ & $\begin{array}{l}-0.011 \\
(0.007)\end{array}$ & $\begin{array}{l}-0.007 \\
(0.006)\end{array}$ & $\begin{array}{l}-0.014 \\
(0.007)\end{array}$ & $\begin{array}{l}-0.014 \\
(0.006)\end{array}$ \\
\hline Model effects $\{353\}$ & Yes & & & & & & \\
\hline Auction year dummies $\{9\}$ & Yes & & & & & & \\
\hline Cohort effects $\{2,366\}$ & & Yes & Yes & Yes & Yes & Yes & Yes \\
\hline $\mathrm{US} \times$ production year trend & & & & Yes & & & \\
\hline Condition dummies & & & & & & & Yes \\
\hline Region and season controls & & & Yes & Yes & Yes & Yes & Yes \\
\hline Mean Dependent Variable & $\begin{array}{l}10.77 \\
{[0.71]}\end{array}$ & $\begin{array}{l}10.96 \\
{[0.64]}\end{array}$ & $\begin{array}{l}10.96 \\
{[0.64]}\end{array}$ & $\begin{array}{l}10.96 \\
{[0.64]}\end{array}$ & $\begin{array}{l}10.97 \\
{[0.70]}\end{array}$ & $\begin{array}{l}10.96 \\
{[0.63]}\end{array}$ & $\begin{array}{l}10.96 \\
{[0.64]}\end{array}$ \\
\hline $\begin{array}{l}\text { Observations } \\
R^{2}\end{array}$ & $\begin{array}{l}42,841 \\
0.89\end{array}$ & $\begin{array}{l}17,153 \\
0.90\end{array}$ & $\begin{array}{l}17,153 \\
0.91\end{array}$ & $\begin{array}{l}17,153 \\
0.91\end{array}$ & $\begin{array}{l}9,664 \\
0.94\end{array}$ & $\begin{array}{l}15,847 \\
0.90\end{array}$ & $\begin{array}{l}17,153 \\
0.91\end{array}$ \\
\hline
\end{tabular}

Notes: Standard errors clustered on production-line are in parentheses. Standard deviations are in brackets. Number of categories in a group is in braces. The dependent variable is the log of the transaction price for the used equipment in 2000 dollars. See note to Table 2 for description of sample and controls.

$\wedge$ Selectivity adjustment 
Table 5: Effect of the Labor Dispute on the US-Foreign Resale Price Differential by Type of Engine Dependent Variable: Log Resale Transaction Price

\begin{tabular}{|c|c|c|}
\hline Explanatory Variables & $\begin{array}{l}\text { (1) } \\
\text { Caterpillar } \\
\text { Engine } \\
\end{array}$ & $\begin{array}{l}\text { (2) } \\
\text { Other Manufacturer's } \\
\text { Engine }\end{array}$ \\
\hline US-Dispute & $\begin{array}{l}-0.037 \\
(0.012)\end{array}$ & $\begin{array}{l}-0.011 \\
(0.026)\end{array}$ \\
\hline Produced in the US & $\begin{array}{l}0.038 \\
(0.014)\end{array}$ & $\begin{array}{l}0.023 \\
(0.02)\end{array}$ \\
\hline Mean Dependent Variable & $\begin{array}{l}10.94 \\
{[0.65]}\end{array}$ & $\begin{array}{l}11.09 \\
{[0.53]}\end{array}$ \\
\hline $\begin{array}{l}\text { Observations } \\
R^{2}\end{array}$ & $\begin{array}{l}15,051 \\
0.91 \\
\end{array}$ & $\begin{array}{l}2,102 \\
0.85 \\
\end{array}$ \\
\hline
\end{tabular}


Table 6: Effect of the labor dispute on the resale rate of construction equipment; Poisson models; dependent variable is the number of pieces of equipment observed more than once in a production line $\times$ production year $\times$ region cell.

\begin{tabular}{|c|c|c|c|c|c|}
\hline $\begin{array}{l}\text { Explanatory } \\
\text { Variables }\end{array}$ & (1) & (2) & (3) & $\begin{array}{l}(4) \\
1992-2000\end{array}$ & $\begin{array}{l}(5) \\
1984-1997\end{array}$ \\
\hline $\begin{array}{l}\text { Log of the total number of } \\
\text { equipment transacted in the cell }\end{array}$ & $\begin{array}{l}1.00 \\
(0.02)\end{array}$ & $\begin{array}{l}0.96 \\
(0.02)\end{array}$ & $\begin{array}{l}0.97 \\
(0.02)\end{array}$ & $\begin{array}{l}0.97 \\
(0.03)\end{array}$ & $\begin{array}{l}0.97 \\
(0.02)\end{array}$ \\
\hline US $\times$ Dispute & $\begin{array}{l}0.19 \\
(0.08)\end{array}$ & $\begin{array}{l}0.15 \\
(0.08)\end{array}$ & $\begin{array}{l}0.26 \\
(0.13)\end{array}$ & $\begin{array}{l}0.22 \\
(0.29)\end{array}$ & $\begin{array}{l}0.24 \\
(0.13)\end{array}$ \\
\hline US & $\begin{array}{l}-0.44 \\
(0.06)\end{array}$ & $\begin{array}{l}-0.35 \\
(0.06)\end{array}$ & $\begin{array}{l}-0.38 \\
(0.11)\end{array}$ & $\begin{array}{l}-0.29 \\
(0.26)\end{array}$ & $\begin{array}{l}-0.41 \\
(0.13)\end{array}$ \\
\hline $\begin{array}{l}\text { Model fixed- } \\
\text { Effects }\{245\}\end{array}$ & No & No & Yes & Yes & Yes \\
\hline Controls & No & Yes & Yes & Yes & Yes \\
\hline $\begin{array}{l}\text { Mean Dependant } \\
\text { Variable }\end{array}$ & $\begin{array}{l}0.33 \\
{[0.79]}\end{array}$ & $\begin{array}{l}0.33 \\
{[0.79]}\end{array}$ & $\begin{array}{l}0.34 \\
{[0.81]}\end{array}$ & $\begin{array}{l}0.36 \\
{[0.87]}\end{array}$ & $\begin{array}{l}0.36 \\
{[0.83]}\end{array}$ \\
\hline $\begin{array}{l}\text { Observations } \\
\text { Log Likelihood }\end{array}$ & $\begin{array}{l}8,527 \\
-5,092 \\
\end{array}$ & $\begin{array}{l}8,527 \\
-5,001 \\
\end{array}$ & $\begin{array}{l}8,110 \\
-4,289\end{array}$ & $\begin{array}{l}4,157 \\
-2,175 \\
\end{array}$ & $\begin{array}{l}7,339 \\
-3,998 \\
\end{array}$ \\
\hline
\end{tabular}

Notes: The dependant variable is the number of pieces of equipment observed more than once in a production-line $\times$ production year $\times$ region cell, conditional on the equipment appearing at least once in US markets. Models with fixed-effects are estimated using a conditional fixed-effects Poisson model. All models include year of production dummies, census region dummies, and a constant. Robust standard errors are in parentheses. Standard deviations are in brackets. Number of categories in a group in braces. The full sample corresponds to equipment model years 1984 through 2000 for transactions occurring between January 1994 and September 2002. Equipment that was ever sold outside the US, and equipment held by Caterpillar for more than one year in inventory is excluded from the analysis. 
Table 8: Effect of the Labor Dispute on the Market for New Equipment Dependent Variable: Log of the List Price of Model Classes

Explanatory

Variables

(1)

(2)

Fraction of equipment

0.018

Produced in the US

(0.008)

Fraction of equipment

$-0.013$

Produced in the US $\times$ Dispute

$(0.006)$

Equipment Produced Exclusively

In the US $\times$ Dispute

$-0.018$

Mean Dependent Variable

$\begin{array}{ll}12.26 & 12.26 \\ {[0.84]} & {[0.84]} \\ 702 & 548 \\ 0.99 & 0.99\end{array}$

Observations

0.99

0.99

Notes: Standard errors clustered on model in parentheses. Standard deviations in brackets. Both models are estimated with model and year fixed effects. There are 180 models included in the first specification and 162 in the second. 
Appendix Table 1

Values of the Monetized Condition Index

\begin{tabular}{l|l|l}
\hline Condition reported as: & Index & $\begin{array}{l}\text { Standard error of the } \\
\text { estimated value }\end{array}$ \\
\hline Excellent & 36.3 & 3.4 \\
Very Good & 32.5 & 3.4 \\
Good & 27.8 & 3.4 \\
No condition reported & 26.8 & 3.4 \\
Fair & 20.0 & 3.4 \\
Poor & 0 & \\
\hline
\end{tabular}

Notes: These are the values of the monetized condition index which are estimated using the procedure described in Appendix B. The R-squared from the regression used to estimate the index is 0.93 . 